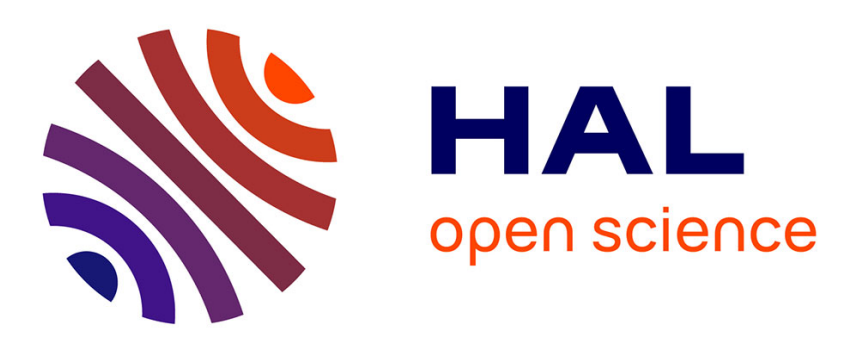

\title{
Effects of ultramafic topsoil stockpiling during mine activities on its microbial diversity and other microbiological and physicochemical characteristics
}

Laurent Bordez, Yvon Cavaloc, Philippe Jourand, Marc Ducousso, Farid Juillot, Hamid Amir

\section{To cite this version:}

Laurent Bordez, Yvon Cavaloc, Philippe Jourand, Marc Ducousso, Farid Juillot, et al.. Effects of ultramafic topsoil stockpiling during mine activities on its microbial diversity and other microbiological and physicochemical characteristics. Ecological Engineering, 2022, 177, pp.106563. 10.1016/j.ecoleng.2022.106563 . hal-03581999

\author{
HAL Id: hal-03581999 \\ https://hal.science/hal-03581999
}

Submitted on 1 Mar 2022

HAL is a multi-disciplinary open access archive for the deposit and dissemination of scientific research documents, whether they are published or not. The documents may come from teaching and research institutions in France or abroad, or from public or private research centers.
L'archive ouverte pluridisciplinaire HAL, est destinée au dépôt et à la diffusion de documents scientifiques de niveau recherche, publiés ou non, émanant des établissements d'enseignement et de recherche français ou étrangers, des laboratoires publics ou privés. 


\section{Ecological Engineering}

\section{Effects of ultramafic topsoil stockpiling during mine activities on its microbiota diversity and other characteristics \\ --Manuscript Draft--}

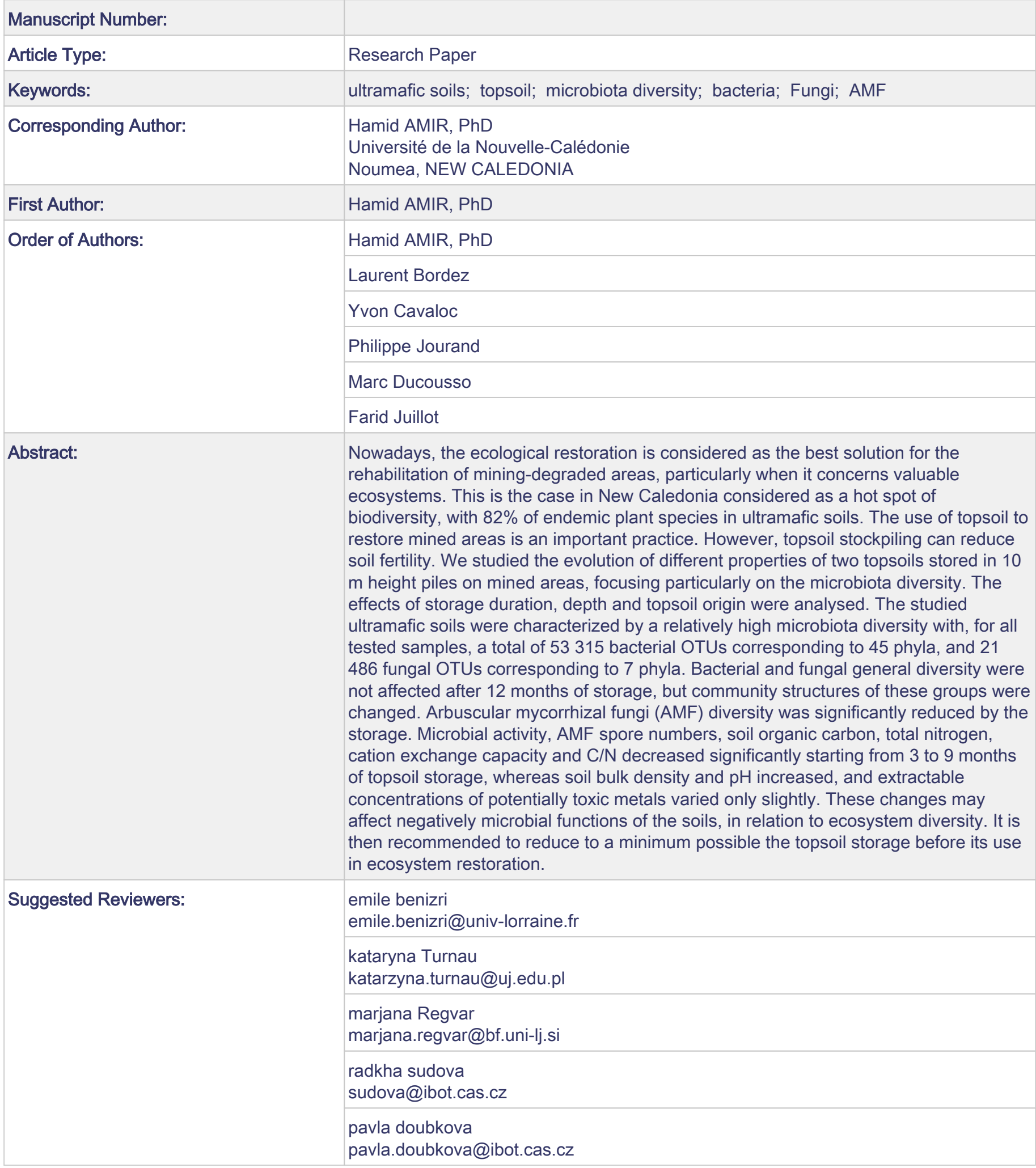




\section{COVER LETTER}

This research article is about changes that occur in ultramafic topsoils during stockpiling operations before ecological restoration of nickel mining-degraded areas.

It concerns biosphere (ecosystem restoration), anthroposphere (mining activity) and lithosphere (ultramafic rocks and nickel ore).

It is a global ecological approach using a multifactorial microbiological and physicochemical characterization of soils evolution during their storage in mines. It is then a contribution to environmental remediation of anthropogenic degradations, including the reduction of erosion and lagoon pollution.

Hamid Amir 


\section{Author statement}

Hamid Amir : Institut des Sciences Exactes et Appliquées (ISEA), Université de la NouvelleCalédonie, Noumea, 98851, New Caledonia ; email : hamid.amir@unc.nc

Laurent Bordez : Institut des Sciences Exactes et Appliquées (ISEA), Université de la NouvelleCalédonie, Noumea, 98851, New Caledonia ; email : laurent.bordez@gmail.com

Yvon Cavaloc : Institut des Sciences Exactes et Appliquées (ISEA), Université de la NouvelleCalédonie, Noumea, 98851, New Caledonia ; mail : yvon.cavaloc@unc.nc

Philippe Jourand : IRD, Laboratoire des Symbioses Tropicales et Méditerranéennes, (LSTM, UMR040), TA A-82/J, 34398 Montpellier cedex 5, France ; email : philippe.jourand@ird.fr

Marc Ducousso : CIRAD, Laboratoire des Symbioses Tropicales et méditerranéennes (LSTM, UMR113), TA A-82/J, 34398 Montpellier cedex 5, France ; email : marc.ducousso@cirad.fr

Farid Juillot : Institut de Mineralogie, de Physique des Materiaux et de Cosmochimie (IMPMC), UMR 7590 CNRS - SU - MNHN - IRD, Sorbonne Universite, case 115, 4 place Jussieu, 75252 Paris Cedex 5, France ; and Institut de Recherche pour le Developpement (IRD), ERL 206 IMPMC, 101 Promenade Roger Laroque, BPA5, 98848 Noumea, New Caledonia ; email : farid.juillot@ird.fr 


\section{Declaration of interests}

$\bigotimes$ The authors declare that they have no known competing financial interests or personal relationships that could have appeared to influence the work reported in this paper.

$\square$ The authors declare the following financial interests/personal relationships which may be considered as potential competing interests:

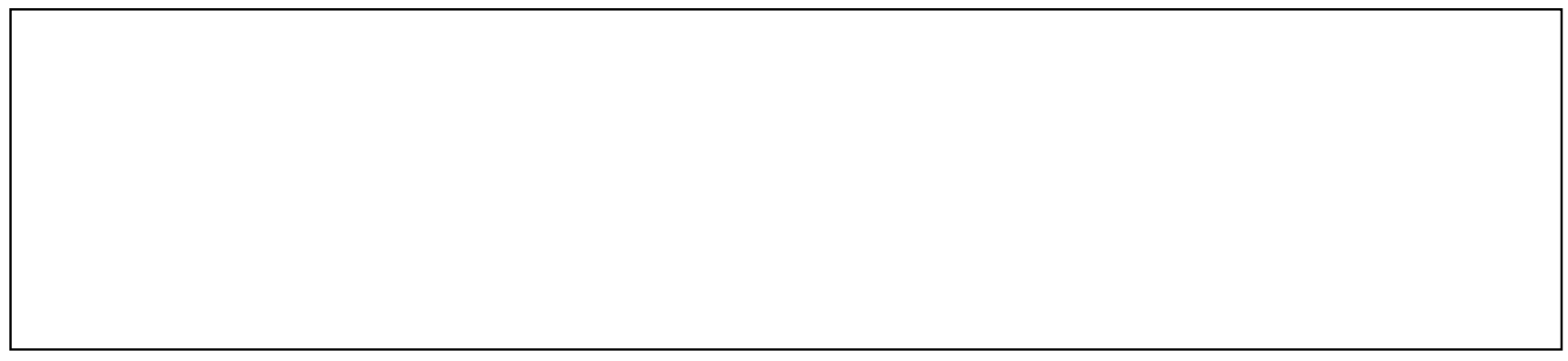




\section{Effects of ultramafic topsoil stockpiling during mine activities on}

\section{2 its microbiota diversity and other characteristics}

3 Hamid Amir a ${ }^{\text {a }}$, Laurent Bordez a, Yvon Cavaloc a Philippe Jourand ${ }^{\text {b }}$, Marc Ducousso c,

4 Farid Juillot ${ }^{d}$

5

6 a Institut des Sciences Exactes et Appliquées (ISEA), Université de la Nouvelle-Calédonie,

$7 \quad$ Noumea, 98851, New Caledonia

8 b IRD, Laboratoire des Symbioses Tropicales et Méditerranéennes, (LSTM, UMRO40),

9 TA A-82/J, 34398 Montpellier cedex 5, France

10 c CIRAD, Laboratoire des Symbioses Tropicales et méditerranéennes (LSTM, UMR113),

11 TA A-82/J, 34398 Montpellier cedex 5, France

12 d Institut de Mineralogie, de Physique des Materiaux et de Cosmochimie (IMPMC),

13 UMR 7590 CNRS - SU - MNHN - IRD, Sorbonne Universite, case 115, 4 place Jussieu,

1475252 Paris Cedex 5, France ; and Institut de Recherche pour le Developpement (IRD),

15 ERL 206 IMPMC, 101 Promenade Roger Laroque, BPA5, 98848 Noumea, New

16 Caledonia

* Corresponding Author: Hamid Amir, Institut des Sciences Exactes et Appliquées

20 (ISEA), Université de la Nouvelle-Calédonie, BP R4 -98851 Noumea Cedex, New

$21 \quad$ Caledonia

22 Email : hamid.amir@unc.nc 


\section{Effects of ultramafic topsoil stockpiling during mine activities on}

26 its microbiota diversity and other characteristics

27 Hamid Amir a ${ }^{\text {* }}$, Laurent Bordez a, Yvon Cavaloc a Philippe Jourand b, Marc Ducousso c,

28 Farid Juillot ${ }^{d}$

a Institut des Sciences Exactes et Appliquées (ISEA), Université de la Nouvelle-Calédonie, 31 Noumea, 98851, New Caledonia

b IRD, Laboratoire des Symbioses Tropicales et Méditerranéennes, (LSTM, UMR040),

TA A-82/J, 34398 Montpellier cedex 5, France

c CIRAD, Laboratoire des Symbioses Tropicales et méditerranéennes (LSTM, UMR113),

TA A-82/J, 34398 Montpellier cedex 5, France

d Institut de Mineralogie, de Physique des Materiaux et de Cosmochimie (IMPMC),

UMR 7590 CNRS - SU - MNHN - IRD, Sorbonne Universite, case 115, 4 place Jussieu,

75252 Paris Cedex 5, France ; and Institut de Recherche pour le Developpement (IRD),

Caledonia.

\section{ABSTRACT}

Nowadays, the ecological restoration is considered as the best solution for the rehabilitation of mining-degraded areas, particularly when it concerns valuable ecosystems. This is the case in New Caledonia considered as a hot spot of biodiversity, with $82 \%$ of endemic plant species in ultramafic soils. The use of topsoil to restore mined areas is an important practice. However, topsoil stockpiling can reduce soil 
$49 \mathrm{~m}$ height piles on mined areas, focusing particularly on the microbiota diversity. The

50 effects of storage duration, depth and topsoil origin were analysed. The studied

51 ultramafic soils were characterized by a relatively high microbiota diversity with, for all

52 tested samples, a total of 53315 bacterial OTUs corresponding to 45 phyla, and 21486

53 fungal OTUs corresponding to 7 phyla. Bacterial and fungal general diversity were not

54 affected after 12 months of storage, but community structures of these groups were

55 changed. Arbuscular mycorrhizal fungi (AMF) diversity was significantly reduced by the

56 storage. Microbial activity, AMF spore numbers, soil organic carbon, total nitrogen,

57 cation exchange capacity and $\mathrm{C} / \mathrm{N}$ decreased significantly starting from 3 to 9 months

58 of topsoil storage, whereas soil bulk density and $\mathrm{pH}$ increased, and extractable

59 concentrations of potentially toxic metals varied only slightly. These changes may

60 affect negatively microbial functions of the soils, in relation to ecosystem diversity. It is

61 then recommended to reduce to a minimum possible the topsoil storage before its use

62 in ecosystem restoration.

63

64 Keywords : Ultramafic soils, topsoil, microbiota diversity, bacteria, fungi, AMF 
66

\section{Introduction}

The soil surfaces stripped by mine activities over the world are constantly rising in relation to the increase of industrial needs, particularly for metals (Deshaies, 2011; Harrison and Rajakaruna, 2011). These practices create important environmental and societal problems (Bradshaw, 1997, Tordoff et al., 2000). Nowadays, ecological restoration is considered as the best option for rehabilitation of these degraded areas (L'Huillier et al., 2010 ; McDonald et al., 2016). Indeed, only this practice can ensure the long-term ecosystem resilience by allowing the reinstallation of at least a part of the original biodiversity. Such a long-term view is vital to face the global crisis affecting the biosphere (Aronson and Alexander, 2013), as stressed by United Nations (UN) general assembly with the proclamation of UN Decade on Ecosystem Restoration for 2021-2030 (Fischer et al., 2020; UN Environment Agency, 2019). However, ecological restoration needs a high level of scientific and technical knowledge, particularly when facing extreme environmental conditions.

In New Caledonia, metal rich ultramafic areas represent one third of the main land containing 20 to $30 \%$ of the world nickel resources (L'Huillier and Jaffré, 2010). These ultramafic substrates are covered by very valuable ecosystems, with a high level of endemism (Isnard et al., 2016), up to $82 \%$ for plants (Morat et al., 2012). These ecosystems are threatened by mine activities, fire and other anthropogenic pressures, and have been listed as one of the world biodiversity hot spots (Myers et al., 2000; Marchese, 2015). The soils of these areas are generally deficient in macronutrients, particularly $\mathrm{P}, \mathrm{K}$ and $\mathrm{N}$, and enriched in potentially toxic metals such as $\mathrm{Ni}, \mathrm{Co}, \mathrm{Cr}$ and Mn (Jaffré and L'Huillier, 2010; Proctor, 2003). In addition, Mg is in excess and thus competes with Ca for root absorption, accentuating the selection pressure on plant species (Jaffré and L'Huillier, 2010; Proctor and Nagy, 1992). Finally, most of these 
91 soils that are colonized by ultramafic maquis (shrub heathlands) are subject to large

92 fluctuations of water availability ranging from waterlogging to drought (Jaffré and

93 L'Huillier, 2010). Despite these extreme conditions, these soils contain an important

94 seed bank (Bordez, 2015; L'Huillier et al., 2010) and a high microbial diversity (Bordez

95 et al., 2016; Gourmelon et al., 2016), including original and efficient populations of

96 mycorrhizal fungi (Perrier et al., 2006; Amir et al., 2014a; 2019; Crossay et al., 2019;

97 Waseem et al., 2017).

98 In relation with these biological properties, the soil stripped during nickel mine

99 activities (generally called topsoil) must be replaced back after mining operations to

100 restore the degraded areas. This practice is considered as fundamental (Ghose, 2001;

101 Sheoran et al., 2010); however the topsoil is often stockpiled before being spread for

102 mined areas restoration (Ghose, 2001). It is frequently the case in New Caledonia,

103 because mines recently operated do not have yet enough surfaces to restore. In other

104 cases, mining activities are not sufficiently coordinated with rehabilitation activities to

105 provide an area for restoration after each stripping operation. Topsoil storage during

106 more than few months can induce a loss of seed bank and a degradation of its fertility

107 (Amir et al. 2014b; Ghose, 2001; Koch, 2007; Stahl et al., 2002). However, only few

108 studies have reported detailed effects of topsoil storage on soil characteristics,

109 including microbiota diversity and structure (Block, 2018; Ezeokoli et al., 2019;

110 Mashigo, 2018). Moreover, to our knowledge, no data on this subject are available for

111 ultramafic topsoils. Yet, the resilience of soil microbiota functions directly depends on

112 microbial community structure (Griffith et al., 2008), in relation to ecological niches of

113 the different taxa, and ecosystem functions also depend on microbiota diversity

114 (Deng, 2012). Different studies reported the covariation of soil microbial and vegetal 
115 communities (Djukic et al. 2010; Yergeau et al. 2010), suggesting that changes in

116 microbiota can induce changes in plant species structure.

117 We studied the evolution of two topsoils stored in $10 \mathrm{~m}$ height piles on mine areas,

118 in New Caledonia. The first topsoil was taken from an open ligno-herbaceous maquis,

119 whereas the second one came from a bushy maquis. We chose a multifactorial

120 approach to analyse the changes that appeared during the storage for microbiota

121 diversity and structure, as well as different other microbial and physico-chemical

122 characteristics. We tested the effects of time storage, depth and topsoil origin.

\section{2. Materials and methods}

\subsection{Site description, topsoil characteristics and sampling}

126 New Caledonia is located approximately $1,500 \mathrm{~km}$ east of Australia and 1,800 km

127 north of New Zealand in the South Pacific. The climate is subtropical to tropical, with a

128 rainy season from December to May and a dry season from September to November.

129 The two sites where the topsoils were stripped are located on the Koniambo massif

130 (Fig. S1). The monthly temperature in Koniambo fluctuates between $14.5^{\circ} \mathrm{C}$ and 21.1

$131{ }^{\circ} \mathrm{C}$, with daily variations of about $5^{\circ} \mathrm{C}$. The average monthly rainfall is about $250 \mathrm{~mm}$

132 during the wet season and $100 \mathrm{~mm}$ during the dry season.

133 The first topsoil pile (called topsoil 1) was obtained by stripping a ligno-

134 herbaceous open maquis at an altitude of 450 to $900 \mathrm{~m}\left(20^{\circ} 59.311^{\prime} \mathrm{S}, 164^{\circ} 49.037^{\prime}\right.$

135 E). The maquis was dominated by the cyperaceous species Costularia nervosa, $C$. 136 araundinacea, Schoenus neocaledonicus and Lepidosperma perteres. The most

137 frequent shrubby species were Nomandia neocaledonica, Hibertia altigena, $H$.

138 pancheri, Eucarpha deplanchei, Montrouziera gabriellae, Myodocarpus floribundus,

139 Codia montana and Ixora francii. 
140 The soil was a highly weathered oxisol (ferralsol) with following physico-chemical

141 characteristics (analysis done before the stripping): pF 4.2: 14.85; clay (\%): 11.5; silt

142 (\%): 27.8; sand (\%): 55.2; $\mathrm{pH}\left(\mathrm{H}_{2} \mathrm{O}\right)$ : 5.44; organic carbon (\%): $2.47 \%$; total $\mathrm{N}(\%)$ : 0.09;

143 total P ( $\mathrm{mg} \mathrm{kg}^{-1}$ ): 120.48; available P (Olsen $\mathrm{mg} \mathrm{kg}^{-1}$ ): 0.00; Ca $\left(\mathrm{g} \mathrm{Kg}^{-1}\right)$ : 0.65; CEC (meq $\left.144100 \mathrm{~g}^{-1}\right): 7.50 ; \mathrm{K} \mathrm{CE}\left(\operatorname{meq} 100 \mathrm{~g}^{-1}\right): 0.08 ; \mathrm{Mg}(\%): 0.78 ; \mathrm{Fe}(\%): 41.60 ; \mathrm{Mn}(\%): 0.41 ; \mathrm{Ni}$

145 (\%): $0.55 ; \quad \mathrm{Cr} \quad(\%): \quad 1.94 ; \quad \mathrm{Co} \quad(\%): 0.08 ; \quad \mathrm{Fe}$ DTPA (extractable by 146 dimethylenetriaminopentaacetic acid, $\mathrm{mg} \mathrm{kg}^{-1}$ ): 77.05; $\mathrm{Mn}$ DTPA (mg kg-1): 667.61; Ni

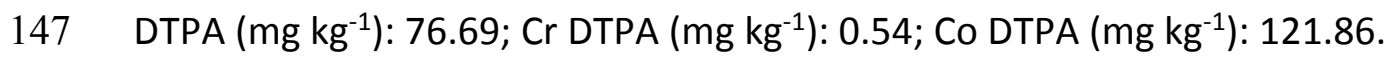

148 The second topsoil pile (called topsoil 2) was obtained by stripping a dense bushy 149 maquis at the same altitude $\left(20^{\circ} 58.331^{\prime} \mathrm{S}, 164^{\circ} 47.618^{\prime} \mathrm{E}\right)$. The main plant species of 150 the ecosystem were: Tristaniopsis Callobuxus, Alstonia spp., Codia montana, Hibbertia 151 Iucens, Metrosideros nitida, Costularia araundinacea, Lepidosmerma perteres. The soil 152 was also a weathered oxisol (ferralsol) with following physico-chemical characteristics 153 (analysis done before the stripping): pF 4.2: 16.07; clay (\%): 11.5; silt (\%): 26.0; sand 154 (\%): 55.0; $\mathrm{pH}\left(\mathrm{H}_{2} \mathrm{O}\right)$ : 5.36; organic carbon (\%): $4.07 \%$; total $\mathrm{N}(\%)$ : 0.13; total P (mg kg$15{ }^{1}$ ): 126.91; available P (Olsen $\mathrm{mg} \mathrm{kg}^{-1}$ ): 0.33; Ca $\left(\mathrm{g} \mathrm{Kg}^{-1}\right)$ : 0.60; CEC (meq 100g ${ }^{-1}$ ): 9.81; K $156 \mathrm{CE}\left(\operatorname{meq} 100 \mathrm{~g}^{-1}\right): 0.11 ; \mathrm{Mg}(\%): 0.82 ; \mathrm{Fe}(\%): 44.6 ; \mathrm{Mn}(\%): 0.41 ; \mathrm{Ni}(\%): 0.48 ; \mathrm{Cr}(\%)$ : 157 1.93; Co (\%): 0.09; Fe DTPA (extractable by dimethylenetriaminopentaacetic acid, mg 158 kg-1): 129.62; Mn DTPA (mg kg-1): 629.21; Ni DTPA (mg kg $\left.{ }^{-1}\right): 108.43 ; \operatorname{Cr}$ DTPA $\left(\mathrm{mg} \mathrm{kg}^{-1}\right)$ : $159 \quad$ 0.27; Co DTPA $\left(\mathrm{mg} \mathrm{kg}^{-1}\right): 112.88$.

160 The two soils and associated vegetation were stripped with a 25-ton articulated 161 hydraulic excavator. The stripped vegetation was integrated to the topsoils. The 162 topsoil piles were placed on relatively flat places and had a height of $10 \mathrm{~m}$ (Fig. S2).

163 Topsoil samples were collected at the constitution of the topsoil piles (t0); and 
165 done on the pile with an excavator and samples were collected at three different

166 depths $(0.1 \mathrm{~m} ; 2 \mathrm{~m} ; 10 \mathrm{~m})$ with a disinfected planter, after scraping of the first $\mathrm{cm}$.

167 Except for the determination of bulk density, soil samples were sieved at $2 \mathrm{~mm}$ mesh.

2.2. General physico-chemical analyses

170 Sieved and dried soil samples were sent were sent to the Laboratoire des Moyens

171 Analytiques (LAMA US IMAGO) of the IRD Noumea Center for physico-chemical

172 characterization (see physico-chemical properties listed above) using standard

173 methods (https://imago.ird.fr/moyens-analytiques/noumea/les-prestations).

\subsection{Soil DNA extraction and bar-coded pyrosequencing of bacteria and fungi}

DNA pyrosequencing analyses were realized at the beginning of the storage and

177 after 12 months for the three depth levels. For each soil sample, eight DNA extractions

178 were performed as replicates from $0.25 \mathrm{~g}$ subsamples using the Mobio PowerSoil

179 extraction kit (MO BIO Laboratories, Inc., Carlsbad, CA, USA). We performed the

180 alternative lysis method proposed by the manufacturer. Soil subsamples were

181 vortexed for $3-4 \mathrm{~s}$ and heated to $70{ }^{\circ} \mathrm{C}$ for 5 min three times. The DNA samples were

182 then stored at $-20{ }^{\circ} \mathrm{C}$ until needed. The bacterial community diversity was assessed

183 using the DNA 545-bp region covering V1-V3 within the $16 \mathrm{~S}$ gene region and

184 considered by Woese (1987) as the broadly conserved DNA barcode. The primers $27 \mathrm{~F}$

185 and 553R were used to amplify this region. The fungal community was analyzed by

186 targeting the DNA region of the ITS2 rRNA gene, which is widely used as a DNA

187 metabarcoding marker (Bates et al., 2013). The primers ITS3 and ITS4 were used to

188 amplify this region. As shown by White et al. (1990), the primer set provides $95 \%$ of

189 fungal and $99 \%$ of Glomeromycota DNA. The full set of primers used is reported in 
190 Table S1. The PCRs were conducted in $25 \mu \mathrm{L}$ reactions with $0.625 \mu \mathrm{L}(0.25 \mu \mathrm{M})$ of each

191 primer, $2.5 \mathrm{ng}$ of the template DNA for each soil subsample, $1 \mathrm{X}$ PCR buffer and $0.08 \mathrm{U}$

192 of GoTaq ${ }^{R}$ Flexi DNA polymerase (Promega Corporation, Madison, WI, USA). The

193 cycling conditions were: initial denaturation at $94{ }^{\circ} \mathrm{C}$ for $3 \mathrm{~min}$; 30 cycles of $94{ }^{\circ} \mathrm{C}$ for

$19430 \mathrm{~s}, 57{ }^{\circ} \mathrm{C}$ for $1 \mathrm{~min}$ and $72{ }^{\circ} \mathrm{C}$ for $1.5 \mathrm{~min}$, and finally a $10 \mathrm{~min}$ extension at $72{ }^{\circ} \mathrm{C}$. The

195 amplified DNA was purified by filtration (Sephadex G50; Sigma-Aldrich, St. Louis, MO,

196 USA) and the product purity was visualized on agarose $1.5 \%$ gel in a TAE buffer. Gels

197 were stained with ethidium bromide $(0.5 \mu \mathrm{g} / \mathrm{mL})$ and visualized under UV light. After

198 DNA quality control, the subsample replicates of PCR products from a same soil

199 sample were pooled to obtain one final amplicon per soil sample for each microbial

200 domain. The DNA concentration of each amplicons was determined using a NanoDrop

201 spectrophotometer (Nano- Drop 2000; Thermo Scientific, Wilmington, DE, USA).

202 Finally, for both bacteria and fungi, 4 libraries of 9 amplicons pooled in equimolar

203 ratios, were generated, as recommended by 454 Life Sciences (Margulies et al., 2005).

204 The pyrosequencing was performed by Beckman Coulter Genomics (Beckman Coulter

205 Genomics, Danvers, MA, USA).

206

207

\subsection{Processing of pyrosequencing data}

208 The quality of the data was analyzed as described by Nilsson et al. (2012) and processed using the Quantitative Insights Into Microbial Ecology (QIIME) toolkit

210 (Caporaso et al., 2010). Bacterial and fungal sequences were quality-trimmed to a

211 score $>25$ and assigned to soil samples based on their barcodes. Ambiguous bases and

212 mismatches in primer sequences were not admitted. Chimeras were checked and

213 removed with the Chimera Slayer algorithm in QIIME. Both bacterial and fungal

214 sequences were binned into operational taxonomic units (OTUs) using a 97\% identity 
215 threshold with uclust (Kunin et al., 2010), and the most abundant sequence from each

216 OTU was selected as a representative sequence for that OTU. Singletons were

217 removed. We used ITSX SOFTWARE (version 1.0.10) (Bengtsson-Palme et al., 2013) to

218 remove non-fungal ITS2 sequences. Taxonomy was assigned to bacterial OTUs by using

219 the Basic Local Alignment Search Tool (BLAST) for each representative sequence

220 against a subset of the SILVA database (the full database filtered at $97 \%$ sequence

221 identity using BLAST) (SILVA SSU 111) (Quast et al., 2013). The fungal pyrosequencing

222 reads were BLASTed against a database of the ITS2 rRNA sequences from UNITE-INSD

223 V6 (Abarenkov et al., 2010) using the species hypothesis (Kõljalg et al., 2013). The

224 percentage similarity to the assigned sequence ranged from $97 \%$ to $98.5 \%$, with an

225 average value of $98.3 \%$. After this step, the unidentified fungi sequences were

226 extracted and BLASTed against the MAARJAM database using a 97\% identity threshold

227 (Opik et al., 2010) to identify the Glomeromycota. According to McMurdie and Holmes

228 (2014), who showed that the rarefaction of microbiome count data is inefficient in the

229 statistical sense, the EDGER package within the $\mathrm{R}$ statistical environment

230 ('EDGERPACKAGE', Robinson et al., 2010), was used to normalize the differential

231 sequencing depth analysis and the OTU composition for the two microbial domains.

232 The 'calcNormFactors' function was used to find a set of scaling factors for the library

233 sizes that minimize the log-fold changes between the samples for most genes. We

234 then generated an OTU normalized matrix for both fungi and bacteria. These new

235 matrixes were used to the downstream statistical analysis.

\subsection{Global microbial activity (carbon mineralisation)}

238 Soil microbial activity is a good index of fertility as it releases mineral elements for 239 plant nutrition. We chose to measure the $\mathrm{CO}_{2}$ produced by microbial respiration, 
240 corresponding to carbon mineralisation. The $\mathrm{CO}_{2}$ can be easily captured and dosed.

241 Each soil sample (40g of equivalent dry soil adjusted to $80 \%$ of retention capacity) was

242 incubated 28 days in an hermetic bottle $(500 \mathrm{~mL})$ containing a small flask with $10 \mathrm{~mL}$

243 of $\mathrm{NaOH} 0.25 \mathrm{~N}$. To avoid the saturation of the $\mathrm{NaOH}$ solution, the flask was replaced

244 after 14 days and the sample was then incubated 14 days more. The $\mathrm{CO}_{2}$ produced

245 was quantified with $0.1 \mathrm{M}$ and $0.5 \mathrm{M} \mathrm{HCl}$ solutions (Joergensen, 1996) for each of the

246 two periods of 14 days and the values were then summed to obtain the final value.

247 Three soil samples, each representing a mix of two, were reacted for each depth and

248 each time of storage.

\subsection{Arbuscular mycorrhizal fungi spore extraction and quantification}

Arbuscular mycorrhizal symbiosis is very important in New Caledonian ultramafic maquis (Amir and Ducousso, 2010; Perrier et al., 2006). It was then of interest to follow up the abundance of arbuscular mycorrhizal fungi (AMF) during topsoil storage. Regarding the high number of samples, we chose to count the viable AMF spores after humid sieving followed by sucrose gradient centrifugation (method modified from Daniels and Skipper, 1982). Four soil samples were used for each time of storage and depth. For each sample, $50 \mathrm{~g}$ of sieved and dried soil were placed in a $255 \mu \mathrm{m}$ mesh sieve adjusted above a $36 \mu \mathrm{m}$ mesh sieve. The soil was then wet sieved through the two sieves and the harvested material in the $36 \mu \mathrm{m}$ mesh sieve was suspended in 20 $\mathrm{mL}$ of water in a $50-\mathrm{mL}$ Falcon tube. A $25-\mathrm{mL}$ sucrose solution $(70 \% \mathrm{v} / \mathrm{w})$ was injected at the bottom of the tube, forming a stepped density gradient that was centrifuged at $800 \mathrm{rpm}$ for $5 \mathrm{~min}$. Spores of AMF were collected from the interface with the sucrose solution, washed with tap water on a $36 \mu \mathrm{m}$ sieve, and transferred to a $50-\mathrm{mL}$ Falcon 
265 aliquots of $100 \mu \mathrm{L}$ were immediately transferred to Petri dishes for spore counting

266 under a stereomicroscope. Only viable spores containing protoplasm and not broken

267 were counted.

268

269

\subsection{Bulk density}

270

As the topsoil situated in depth inside the piles can be compressed, it was Regarding the possible compression of soil within the piles, it was important to measure the changes of the bulk density during topsoil storage. This analysis was done by weighting $300 \mathrm{~cm} 3$ of non-sieved soil, before and after drying at $105^{\circ} \mathrm{C}$ during $72 \mathrm{~h}$.

274 Then we calculated two parameters: i) the bulk density value $\rho\left(\mathrm{g} \cdot \mathrm{cm}^{-3}\right)$ as the 275 mass/volume ratio of the dry soil; ii) the Water-Filled Pore Space (Robertson and 276 Groffman, 2015) as WFPS $=($ TE $\times 100 \times \rho) /(1-(\rho / \rho S))$, where TE is the soil water 277 content in $\%$ (soil dried $72 \mathrm{~h}$ at $105^{\circ} \mathrm{C}$ ). Four soil samples were tested for each level and 278 topsoil pile.

\subsection{Statistical analyses}

The statistical analyses were performed using R statistical environment ('VEGAN

PACKAGE', R.3.1.1, R foundation). The differences between the variable means were tested with a permutational multivariate analysis of variance (PERMANOVA). In case of significant differences, PERMANOVA pairwise comparisons were used to identify the differences. The results were illustrated by nonmetric multidimensional scaling

286 (NMDS) analysis. The relationship between fungal or bacterial communities and edaphic variables was tested using spearman correlation (PRIMER V7). When a

288 significant relationship was found, a distance-based linear model (DISTLM) was built to identify the significant predictors edaphic variables. This model does a partitioning of 
variation using a multiple regression model. Permutation methods are used to assess

291 statistical significance of each predictor variable. In addition, preliminary diagnostics

292 are made to assess and to avoid multicollinearity among predictor variables that could

293 bias the results (McArdle and Anderson, 2001).

\section{Results}

\subsection{Changes in the composition of bacterial communities}

From the 454-pyrosequencing data, we obtained global numbers of 138932 and

269046 exploitable sequences of bacteria respectively for topsoil 1 and topsoil 2 .

These sequences could be classified in 24382 OTUs for topsoil 1 and 33449 OTUs for topsoil 2. At the beginning of the storage (t0) the mean number of OTUs was 2917 for topsoil 1 and 4730 for topsoil 2 which has a significantly higher bacterial diversity (Fig. 1). This diversity did not change significantly after 12 months of storage whatever the depth considered.

304 A total of 45 bacterial phyla were identified. Overall, for the two topsoils and the three depths, the dominant phyla were: Proteobacteria $(43.0 \pm 2.9 \%)$, Acidobacteria

306 (29.1 $\pm 1.6 \%)$, Actinobacteria $(13.0 \pm 0.2 \%)$, Planctomyces $(8.4 \pm 1.1 \%)$, Chloroflexi (5.8

$307 \pm 0.7 \%)$, Verucomicrobia $(5.1 \pm 0.8 \%)$, Bacteroidetes $(4.1 \pm 1.4 \%)$, Firmicutes $(2.7 \pm$ 308 0.4\%). The other phyla accounted for less than 2\% each (Fig. 2A). The same bacterial 309 orders were present in the two topsoils (Fig. 2B). After 12 months of storage, these

310 taxa differed on their relative abundance. Respectively $45 \%$ and $50 \%$ of the observed 311 differences between t0 and t12 were due to the variations in 12 taxa. It corresponded 312 mainly to a reduction of the abundance of Planctomycetales, Rhodospirillales, 313 Acidobacteriaceae and Chtoniobacterales, and an increase of the abundance of 
315 of the abundance values and corresponding standard errors for the different taxa are 316 given in table S2.

317 A non-metric multidimensional scaling (NMDS) ordination (Fig. 3) showed

318 significant differences $(p<0.001)$ of the bacterial OTU assemblages, between the two 319 storage periods tested (t0 and t12), and this for the two topsoils. These latter were 320 also clearly different for their bacterial community structure $(p<0.001)$. No 321 differences were detected between the three topsoil depths. Furthermore, the 322 distance based linear model (DISTLM) approach (Fig. S3) showed that $16 \%$ of the 323 variability between t0 and t12 storage periods was explained significantly by 324 variations, during the storage, of $\mathrm{pH}$ (for $10 \%$ of the variability) and organic carbon (6\% 325 of the variability).

\subsection{Changes in the composition of fungal communities}

The global numbers of exploitable fungal sequences obtained were 181096 and 307254 respectively for topsoil 1 and topsoil 2 . These sequences were classified in 9357 fungal OTUs for topsoil 1 and 11779 for topsoil 2. The number of fungal OTUs at t0 was 533 for topsoil 1 and 965 for topsoil 2, which has a significantly higher fungal diversity (Fig. 4). Except for a significant increase of the fungal diversity after 12 months at the surface layer of topsoil 1, the other samples did not show any significant differences in relation with the time of storage or the depth.

336 Ascomycota (46.2 $\pm 5.7 \%)$ and Basidiomycota (25.6 $\pm 7.2 \%)$ (Fig. 5A). The non-

337 identified phyla represented $28.4 \pm 0.2 \%$. The other phyla were less abundant 338 Zygomycota (3.3 \pm 0.5\%), Chytridiomycota (> 1\%), Glomeromycota (> 1\%), 
340 after 12 months of storage for the two topsoils, with a reduction of the Basidiomycota

341 abundance and an increase of the Ascomycota and the unidentified phyla abundance.

342 The two topsoils significantly differed for fungal community structure $(p<0.001)$. A

343 total of 41 fungal classes were identified. Among them 10 were dominant (Fig. 5B).

344 Moreover, 68.3\% (topsoil 1) and 69.8\% (topsoil 2) of the observed changes after 12

345 months of storage were related to a reduction of the Agaricomycetes, and an increase

346 of the Sordariomycetes and an unidentified group. Details of the abundance values

347 and corresponding standard errors for the different taxa are given in table S3.

348 NMDS ordination (Fig. 6) showed that significant changes in the fungal OTU 349 assemblages appeared after 12 months of storage for the two topsoils $(p<0.001)$, but

350 without significant effect of the depth. The DISTLM approach (Fig. S4) indicated that $35129.3 \%$ of these changes in fungal communities during topsoil storage were explained 352 by variation in $\mathrm{pH} \mathrm{H}_{2} \mathrm{O}(13.4 \%)$, carbon mineralization (7.3\%), extractable $\mathrm{Mn}$ content 353 (4.4\%) and exchangeable $\mathrm{K}(4.3 \%)$.

354 Arbuscular mycorrhizal fungi (AMF) sequences (Glomeromycota) were also 355 analysed; respectively 77 and 177 sequences were obtained for Topsoil 1 and Topsoil 356 2. At t0, these sequences corresponded respectively to 22 and 47 OTUs (Fig. 7), 357 Topsoil 2 being significantly richer. After 12 months of storage, the number of OTUs 358 decreased significantly (i.e. 3 to 4 times), for the two topsoils. Overall, the depth did 359 not affect the OTUs number, except for $10 \mathrm{~m}$ depth in Topsoil 1 which showed 360 significantly less OTUs than those of the two other depths. The structure of AMF 361 communities was affected by the storage for the two topsoils. However, the OTU 362 numbers for each taxa were too small to obtain reliable statistical analysis (data not 363 shown). 
365

366

367

368

369

370

371

372

373

374

375

376

377

378

379

380

381

382

383

384

385

386

387

388

\subsection{Evolution of the global microbial activity}

Global microbial activity expressed by microbial respiration in the incubated soil samples was negatively affected by the topsoil storage (Fig. 8). In topsoil 1 , the activity dropped significantly (i.e. 5 to 7 times) after 6 months and then tended to stabilize. The same dynamic was observed for topsoil 2, but with a lower reduction of the activity. Some values (between 3 and 9 months) were significantly lower at the deepest layer in comparison with the surface of the piles. Negative correlations between microbial activity on the one hand and depth and bulk density on the other hand were detected (respectively $r=-0.338, p<0.01$ and $r=-0.330, p=0.01$ ).

\subsection{Evolution of AMF viable spore numbers}

The number of viable AMF spores in topsoil 1 dropped significantly 3 times, after 3 months of storage in the surface of the topsoil pile and more than 4 times after 6 months, before stabilizing until 18 months (Fig. 9). In topsoil 2, the decrease was less rapid until 6 months, but the decline was finally stronger (i.e. 10 times) after 12 months. A significant difference between the two topsoils for this parameter was detected $(p<0.001)$. The reduction of viable spore numbers was significantly stronger in the deepest layer for the two topsoil piles during the first period (i.e. 6 to 9 months), before dropping equally for all depths. A negative correlation between the number of viable spores and the depth was noted $(r=-0.527, p<0.0001)$. AMF viable spore richness was also negatively correlated to bulk density $(r=-0.322, p<0.01)$, and positively correlated to organic carbon $(r=0.412, p<0.0001)$, and Cation Exchange Capacity $(r=0.42, p<0.0001)$. 
390 Topsoil bulk density varied similarly (i.e. from $1.2-1.3 \mathrm{~g} \cdot \mathrm{cm}^{-3}$ to $1.8-1.9 \mathrm{~g} . \mathrm{cm}^{-3}$ ) for

391 the two topsoil piles during storage (Fig 10). Soil density increased mostly during the

392 first three months. However, differences between the three tested depths were

393 significant only after 9 months, with higher densities in the deepest layer $(10 \mathrm{~m})$. The

394 Water-Filled Pore Space (Fig. 10) did not change significantly (i.e. from 50 to 53 \%) in

395 the surface layer during storage. However, this parameter showed a significant

396 decrease in the deepest layer after 9 and 18 months of storage for topsoil 1 and after

3976 months of storage for topsoil 2.

398 The organic carbon stock in topsoil 1 decreased from $31 \mathrm{~g} \cdot \mathrm{kg}^{-1}$ to less than $10 \mathrm{~g} \cdot \mathrm{kg}^{-}$

3991 after 9 months storage, with significant differences compared to the initial soil (t0)

400 that after 6 months storage (Fig. 11). In topsoil 2, the loss in organic carbon after 9

401 months storage was lower (i.e. from $42 \mathrm{~g}_{\mathrm{kg}} \mathrm{kg}^{-1}$ to $20 \mathrm{~g} \cdot \mathrm{kg}^{-1}$ ). For the two topsoils, no

402 significant differences were detected between the three depths. The dynamic of total

403 nitrogen was very close to that of organic carbon (Fig. 11). Organic carbon and total

404 nitrogen were negatively correlated with the duration of storage (respectively $r=-$

$4050.417, p=0.0001 ;$ and $r=-0.324, p=0.01)$.

406 The $\mathrm{pH}$ values (Fig. S5) increased from 5.4 to 6.2 during storage in topsoil 1 and

407 from 5.2 to 6.6 in topsoil 2. Significant differences appearing after 3 to 6 months of

408 storage. Overall, $\mathrm{pH}$ values were higher in the deep layers of the piles. The $\mathrm{C} / \mathrm{N}$ values

409 (Fig. S6) dropped significantly from 23-25 to 3-5 after three months of storage for the

410 two topsoils. The values did not vary significantly for longer duration of storage.

411 Among the other physico-chemical parameters that have been followed (Table S4),

412 it can be noticed that topsoil storage induced a reduction of CEC, exchangeable $\mathrm{K}$ and

413 Ca as well as the $\mathrm{Ca} / \mathrm{Mg}$ ratio after 6 to 9 months for the two topsoils. In topsoil 1 ,

414 extractable $\mathrm{Fe}, \mathrm{Ni}, \mathrm{Mn}$ and Co decreased significantly after 3 to 9 months of storage, 
415 whereas extractable $\mathrm{Cr}$ increased 6 to 10 times after three months of storage and then

416 stabilized. In topsoil 2, only extractable Fe was reduced and extractable Co increased

417 after three months of storage, before stabilizing.

418

419 4. Discussion

420 The storage of $10 \mathrm{~m}$ height piles of ultramafic topsoils during 18 months induced 421 modifications of their microbiota structure and affected different other characteristics.

\subsection{Effects of topsoil stockpiling on microbiota diversity}

Despite their extreme edaphic characteristics related to the ultramafic nature of

their parent rocks, the studied soils from ultramafic ecosystems, showed unexpectedly

high microbial diversity richness (4730 bacterial OTUs and 965 fungal OTUs for topsoil

2), comparable to those reported for temperate forests or Amazonian forests (Bordez et al., 2016). In a previous study, Gourmelon et al. (2016) found similar results for different other ultramafic soils from New Caledonia. This high richness is consistent with Mouillot et al. (2013) assertion that ultramafic ecosystems host highly complex microbial communities. Topsoil 2, from a bushy maquis with a denser vegetation, was characterized by a higher bacterial and fungal diversity. This relation between ecosystem productivity and microbial diversity richness agrees with different reported studies for other types of ecosystems (Cong et al., 2015; Kennedy et al., 2005; Li et al. 2015). Bordez et al. (2016) showed that the gradient in vegetation density and productivity of 6 ultramafic ecosystems from New Caledonia is the main factor driving

437 microbial diversity richness, even if the edaphic properties (especially total $\mathrm{N}, \mathrm{pH}$ and CEC) also influence the richness of microbial communities. 
In the present study, the microbiota global diversity of the two topsoils was not

440 affected by 12 months storage. Bacterial and fungal OTU numbers were not

441 significantly different compared to the non-stored control topsoil, whatever the depth

442 considered. At the order level, all taxa survived during topsoil storage, at least at a low

443 abundance. In a study comparing a 5-years stockpiled topsoil with the non-mined

444 corresponding topsoil, Ezeokoli et al. (2019) found a higher microbiota diversity in the

445 latter. The duration of storage can probably explain the differences with our study.

446 Indeed, in our experiment organic carbon and mineralization activity started to decline

447 only after 6 to 9 months of storage. The number of cultivable aerobic bacteria also

448 dropped significantly starting from 6 to 9 months and was only 7 times lower after 12

449 months (data given in Bordez, 2015). Some species becoming rare after 12 months

450 could thus disappear from the stored topsoil after few years. In fact, contrary to the

451 diversity, the structure of microbial communities changed after 12 months of storage.

452 For bacteria, these changes were mainly driven by variations on the relative

453 abundance of 12 taxa (at the order level), some of them showing a decreasing

454 abundance and others showing an increasing abundance. Fungal taxa showed a similar

455 type of changes, with variations in the relative abundance of three classes.

456 Studies discussing variations in microbial taxa composition in relation with soil

457 properties are relatively recent and quite limited in number. Among these studies,

458 Gourmelon et al. (2016) found the same 4 dominant bacterial phyla than those found

459 in the present study (i.e. Proteobacteria, Planctomyces, Acidobacteria and

460 Actinobacteria) in different ultramafic soils from New Caledonia. The domination of

461 Proteobacteria, Acidobacteria and Actinobacteria was also reported by other studies

462 in different soil types and conditions (Herrera et al., 2007; Ko et al., 2017; Liang et al., 
464 the soil, with an increase of Acidobacteria in relation with carbon reduction caused by

465 microbial activity. In our study, Acidobacteria did not vary with depth and reduction of

466 organic carbon after 12 months of storage. However, the DISTLM analysis indicated

467 that the reduction of organic carbon caused by microbial activity affected the bacterial

468 community structure of the two stockpiled topsoils. As observed by Waldropt et al.

469 (2006) and Lauber et al. (2008), organic carbon reduction can have different

470 consequences, particularly in terms of competition and starvation of a part of the

471 microbiota. In our study, the phyla of Planctomycetes was less represented after 12

472 months of topsoil storage in comparison with the non-stored ones. This phylum has

473 indeed been reported as sensitive to soil history (Buckley et al., 2006). Our DISTLM

474 analysis also detected an effect of soil $\mathrm{pH}$ on the bacterial community structure. Soil

$475 \mathrm{pH}$ is commonly reported as regulating the structure of microbiota communities

476 (Lauber et al., 2008; Rousk et al., 2010; Sheng et al., 2019). In our case, it is interesting

477 to note that Acidobacteria, the second most important bacterial phylum in the studied

478 topsoils, declined after storage in topsoil 2 where the $\mathrm{pH}$ value raised from 5.2 to 6.5 .

479 This result is in agreement with Sait et al. (2006) who indicated that Acidobacteria

480 grow optimally from $\mathrm{pH} 4$ to 5.5 and poorly or not at all for $\mathrm{pH}$ above 6.5.

481 Concerning fungi, Ascomycota and Basidiomycota were generally dominant in our

482 study. This result is in agreement with previous studies on ultramafic soils from New

483 Caledonia (Bordez et al., 2016; Gourmelon et al., 2016) and on other soil types (Karst

484 et al., 2013; Ko et al., 2017; Weber et al., 2013; Wang et al., 2020). The main detected

485 variables that were found to structure these communities were $\mathrm{pH}$, carbon

486 mineralization, exchangeable $\mathrm{K}$ and DTPA extractable $\mathrm{Mn}$. The statistical analysis

487 showed that the relative importance of the Basidiomycota was positively correlated

488 with organic carbon $(p=0.02)$ and carbon mineralisation $(p<0.01)$ (data not shown). 
489 Indeed, we observed a clear reduction of the Basidiomycota group after 12 months of

490 topsoil storage, as carbon concentration and $\mathrm{C} / \mathrm{N}$ dropped drastically. This phylum is

491 known for its ability to decompose organic matter, particularly litter and wood

492 (Purahong et al., 2016; 2018; Wang et al., 2020). In addition, many Basidiomycota

493 species are ectomycorrhizal and may then be disturbed by the topsoil storage. Among

494 the Basidiomycota, the class of Agaricomycetes was dominant, which is frequently

495 reported in similar studies (Karst et al., 2013; Ko et al., 2017; Sheng et al., 2019).

496 Inversely, Ascomycota were more represented after 12 months of storage, particularly

497 in deep layers. This result can probably be linked to the high resistance of this group to

498 many soil stresses (Egidi et al., 2019), such as pH variations and organic carbon

499 rarefaction. Indeed, Ascomycota are mostly saprotroph with a large variety of

500 enzymes that enable them to use recalcitrant substrates (Ko et al., 2017).

501 AMF communities were also relatively diverse, with 22 and 47 OTUs found for the

502 two non-stored topsoils. On average, these values correspond to those reported for

503 different other soil types (Schechter and Burns 2008; Yu et al. 2012; Hassan et al.

504 2014; Kruger et al. 2017). The 12 months storage clearly reduced this diversity for the

505 two topsoils. As obligatory symbionts, AMF can survive mainly as spores in absence of

506 plants, but the spores were also affected as indicated by the reduction of their

507 numbers during the storage. Regarding the ecological importance of AMF in ultramafic

508 soils from New Caledonia (Amir et al., 2010; Amir et al., 2019; Crossay et al. 2019), this

509 reduction of AMF diversity and density in stored topsoils may slow down the relative

510 growth of plant species in restored areas. According to Birnbaum et al. (2017), AMF

511 communities of stockpiled sandy topsoils naturally recolonized by plants take 5 to 10

512 years, before returning to their initial level. 
513 Other changes can also influence the structure of the microbiota in relation with

514 the specific needs of each taxa. A compaction of the soil after 12 months of storage

515 has been noted for the three topsoil layers, particularly in the $10 \mathrm{~m}$ depth layer. Such

516 an increase of the bulk density with the depth has also been observed by Ezeokoli et

517 al. (2019) in stockpiled soils. This increase can create an anoxia and inhibit taxa that

518 require high concentrations of oxygen.

4.2. Effects of topsoil stockpiling on some physico-chemical and microbiological

521 properties

522 The evolution of bulk density and water-filled pore space values showed that the

523 two studied topsoils have been compacted during the first months of storage, 524 especially in deep layers. The sandy nature of the soils (i.e. $55 \%$ sand fraction) and 525 their relatively low organic C contents suggest that compaction could have been 526 driven by aggregates destruction upon driving rain and high pressure in deep layers.

527 Such a compaction effect with reduction of soil aggregates has been reported by other 528 studies for stockpiled topsoils (Abdul-kareem and McRae, 1984; Strohmayer, 1999;

529 Wick et al., 2007). Organic $\mathrm{C}$ and total $\mathrm{N}$ contents decreased 2 to 3 times after 9 530 months of storage, without significant differences between the three tested depth 531 levels. Several studies showed a reduction of organic matter in stored soils (Visser et 532 al., 1984; Harris and Birch, 1989; Gobat et al., 2010; Birnbaum et al., 2017) as a 533 consequence of microbial mineralization in absence of any carbon flux. This 534 assumption is supported by our results, which showed a positive correlation between 535 organic $\mathrm{C}$ and microbial activity. We also observed a strong decrease, before 536 stabilization, of the microbial activity after 6 months of storage in the two topsoils, in 
537 agreement with those from other studies (Visser et al., 1984; Harris et al., 1989;

538 Strohmayer, 1999).

539 Other chemical properties showed some variations in relation to organic matter

540 reduction, and/or leaching after driving rains during topsoils storage. Among those,

541 CEC, as well as exchangeable $\mathrm{K}$ and $\mathrm{Ca}$ decreased after 3 to 9 months of storage.

542 However, no significant differences could be found between the three tested depths.

543 Organic carbon reduction and leaching can also explain the reduction of extractable

$544 \mathrm{Fe}, \mathrm{Mn}$ and Co, since the fraction of these metals that is associated with organic

545 matter through complexation is usually the most extractable (McGrath, 1996; Menzies

546 et al., 2007). This explanation is supported by the lack of variation of extractable Fe,

$547 \mathrm{Mn}$ and Co in topsoil 2 where organic carbon reduction is much lower. The increase of 548 extractable $\mathrm{Cr}$ during storage can also be attributed to organic carbon reduction since

549 organic matter is known to counteract $\mathrm{Cr}$ oxidation by $\mathrm{Mn}$-oxides and thus to reduce 550 Cr extractability in soils (Fendorf et al., 1992; 1995).

\section{Conclusions}

553 The two topsoils stockpiled in mine conditions during 18 months showed different 554 modifications of their microbiota diversity and other microbiological and physicochemical properties. Overall, these variations differed significantly for the two topsoils

556 and some were influenced by the depth of storage. Our results thus suggest that New

557 Caledonian ultramafic soils are sensitive to management during mine activities. If the 558 changes in physico-chemical characteristics in these conditions are relatively well 559 known, the perturbations induced on microbiota community structure of the stored 560 topsoils must be regarded with attention, considering the possible degradations of soil 561 microbial functions (Griffith et al., 2008; Ezeokoli et al., 2019). Indeed, some studies 
562 reported variations of the structure of plant communities in relation to differences of

563 microbial communities (Djukic et al., 2010; Yergeau et al., 2010). Yu et al. (2012) found

564 a clear relationship between root-associated fungal communities and plant health

565 status. Changes on microbial community structure upon topsoil stockpiling could thus

566 induce degradations of soil functions and then perturbations of the dynamic of the

567 reconstructed ecosystems. Considering all the above-mentioned results, the duration

568 of the stockpiling of ultramafic topsoils should be reduced as far as possible and in all

569 cases should not exceed 6 months. It is also recommended to reduce the height of the

570 stockpiles when possible to $1 \mathrm{~m}$ or less to minimize the compaction and the 571 anaerobiosis (Amir et al., 2014b).

572

573 Acknowledgments

574 The authors gratefully acknowledge CNRT Koniambo Nickel Society for providing the

575 financial support.

576

577 Supplementary data

578 Supplementary data associated with this article can be found online at: doi...

579

580 Author Contribution

581 H. A. supervised and designed the research, provided the funding and wrote the

582 manuscript; L. B. realized the research studies, contributed to their design and 583 checked the manuscript text; Y. C. contributed to the design and supervision of 584 molecular studies; P. J. contributed to the design and supervision of molecular studies 585 and checked the manuscript text; M. D. contributed to the supervision and checked 
586 the manuscript text; F. J. contributed to the supervision of physico-chemical

587 characterizations and their interpretation and checked the manuscript text.

588

589 References

590 Abdul-Kareem A.W., McRae S.G., 1984. The effects on topsoil of long-term storage in $591 \quad$ stockpiles. Plant Soil 76, 357-363.

592 Amir H., Ducousso M., 2010. Les bactéries et les champignons du sol sur roches 593 ultramafiques, In : L'Huillier L, Jaffré T, Wulff A (Eds), Mines et environnement en $594 \quad$ Nouvelle-Calédonie : les milieux sur substrats ultramafiques et leur restauration. 595 IAC Ed., Noumea, pp. 129-145.

596 Amir H., Jourand P., Cavaloc Y., Ducousso M., 2014a. Role of mycorrhizal fungi on the 597 alleviation of heavy metal toxicity on plant, In: Solaiman Z, Abbott L, A. Varma A, 598 (Eds), Mycorrhizal fungi: Use in sustainable agriculture and forestry. Soil Biology 599 Series, Springer, Heidelberg, pp. 241-258.

600 Amir H., L'Huillier L., Fogliani B., Cavaloc Y., Jourand P., Ducousso M., Majorel C., 601 Hannibal L., Saintpierre D., Gunkel P., Pagand P., Echevarria G., Mouchon L.C., Bonis 602 M.L., Montargues-Pelletier E., Maggia L., Wulff A., 2014b. Caractérisation et 603 fonctionnement du système sol/ plante/ microorganismes dans les maquis miniers. 604 Perspectives d'application à la restauration écologique. Rapport Final- Projet 605 ECOMINE BIOTOP - CNRT « Nickel et son environnement. Edition CNRT, 315 p.

606 Amir H., Cavaloc Y., Laurent A., Pagand P., Gunkel P., Lemestre M., Médevielle V., Pain 607 A., McCoy S., 2019. Arbuscular mycorrhizal fungi and sewage sludge enhance 608 growth and adaptation of Metrosideros laurifolia on ultramafic soil in New 609 Caledonia: a field experiment. Sci. Total Environ. 651, 334-343. 
610 Aronson J., Alexander S., 2013. Ecosystem Restoration is Now a Global Priority: Time

611 to Roll up our Sleeves. Restor. Ecol. 21, 293-296.

612 Bates S.T., Ahrendt S., Bik H.M., Bruns T.D., Caporaso J.G., Cole J., Dwan M., Fierer N.,

613 Gu D., Houston S., Knight R., Leff J., Lewis C.,. Maestre J.P., McDonald D., Nilsson

614 R.H.,Porras-Alfaro A., Robert V., Schoch C., Scott J., Taylor D.L., Parfrey L.W., Stajich

615 J.E., 2013. Meeting Report: Fungal ITS Workshop ( October 2012 ). Standards in 616 Genomic Sciences. 8.

617 Bengtsson-Palme J., Ryberg M., Hartmann M., Branco S., Wang Z., Godhe A., De Wit 618 P., Sánchez-García M., Ebersberger I., de Sousa F., Amend A.S., Jumpponen A., 619 Unterseher M., Kristiansson E., Abarenkov K., Yann B., Y., Sanli K., Eriksson K.M., 620 Vik U., Veldre V., Nilsson R.H., 2013. Improved software detection and extraction of 621 ITS1 and ITS2 from ribosomal ITS sequences of fungi and other eukaryotes for 622 analysis of environmental sequencing data (M Bunce, Ed,). Methods Ecol. Evol. 4, $623914-919$.

624 Birnbaum C., Bradshaw L.E., Ruthrof K.X., Fontaine J.B., 2017. Topsoil stockpiling in 625 restoration: Impact of storage time on plant growth and symbiotic soil biota. Ecol. 626 Restor. 35, 237-245.

627 Block P.R., 2018. Monitoring the effects of surface coal-mine-reclamation on soil 628 biological properties. Master thesis. Nord Dakota State University. Nord Dakota.

629 Bordez L., 2015. Stratégies de revégétalisation des maquis miniers nickelifères de $630 \quad$ Nouvelle-Calédonie: étude sur les potentiels biologiques des topsoils et leur gestion 631 en vue de leur utilisation pour la restauration écologique des milieux degradés. PhD 632 thesis, Université de la Nouvelle-Calédonie, Noumea.

633 Bordez L., Jourand P., Ducousso M., Carriconde F., Cavaloc Y., Santini S., Claverie J.M., 634 Wantiez L., Leveau A., Amir H., 2016. Distribution patterns of microbial 
635

636

637

638

639

640

641

642

643

644

645

646

647

648

649

650

651

652

653

654

655

656

657

658

communities in ultramafic landscape: a metagenetic approach highlights the strong relationships between diversity and environmental traits. Mol. Ecol. 25, 2258-2272.

Bradshaw A., 1997. Restoration of mined lands - using natural process. Ecol. Eng. 8, 255-269.

Caporaso J.G., Kuczynski J., Stombaugh J., Bittinger K., Bushman F.D., Costello K.E., Fierer N., Peña A.G., Goodrich J.K., Gordon J.I., Huttley G.A., Kelley S.T., Knights D., Koenig J.E., Ley R.E., Lozupone C.A., McDonald D., Muegge B.D., Pirrung M., Reeder J., Sevinsky J.R., Turnbaugh P.J., Walters W.A., Widmann J., Yatsunenko T., Zaneveld J., Knight R., 2010. QIIME allows analysis of high-throughput community sequencing data. Nat. methods 7, 335-336.

Cong J, Yang Y, Liu X et al. (2015) Analyses of soil microbial community compositions and functional genes reveal potential consequences of natural forest succession. Sci. Rep-UK 5, 10007.doi: 10.1038/srep10007.

Crossay T., Majorel C., Redecker D., Gensous S., Medevielle V., Durrieu G., Cavaloc Y., Amir H., 2019. Is a mixture of arbuscular mycorrhizal fungi better for plant growth than single-species inoculants? Mycorrhiza 29, 325-339.

Daniels, B. A., Skipper, H. D., 1982. Methods for the recovery and quantitative estimation of propagules from soil, In: Schenck. N. C. (Ed.), Methods and Principles of Mycorrhizal Research. Amer. Phytopath. Soc, St. Paul, Minnesota. pp. 29-35.

Deng H., 2012. A review of diversity-stability relationship of soil microbial community: What do we know? J. Soil Environ. 24, 1027-1035.

Deshaies M., 2011. Grands projets d'exploitation minière et stratégie des firmes pour se rendre environnementalement acceptables. L'Espace Politique 15-3 Firmes et géopolitiques, DOI : 10.4000/espacepolitique.2113. 
659 Djukic I., Zehetner F., Mentler A., Gerzabek M.H., 2010. Microbial community 660 composition and activity in different Alpine vegetation zones. Soil Biol. Biochem. $661 \quad 42,155-161$.

662 Egidi E., Delgado-Baquerizo M., Plett J.M., Wang J., Eldridge D.J., Bardgett R.D., 663 Maestre F.T., Singh B.K., 2019. A few Ascomycota taxa dominate soil fungal 664 communities worldwide. Nat. Commun. 10, 2369. doi.org/10.1038/s41467-019$665 \quad$ 10373-z.

666 Ezeokoli O.T., Mashigo S.K., Paterson D.G., Bezuidenhout C.C., Adeleke R.A., 2019. 667 Microbial community structure and relationship with physicochemical properties of 668 soil stockpiles in selected South African opencast coal mines. Soil Sci. Plant Nutr. 65, $669 \quad 332-341$.

670 Fendorf S.E. and Zasoski R.J., 1992. Chromium (III) oxidation by ?]? ? 671 Characterization. Environ. Sci. Technol. 26, 79-85. doi.org/10.1021/es00025a006

672 Fendorf S.E., 1995. Surface reaction of chromium in soils and waters. Geoderma 67, 673 55-71. doi.org/10.1016/0016-7061(94)00062-F

674 Fischer J., Riechers M., Loos J., Martin-Lopez B., Temperton V.M., 2021. Making the UN 675 Decade on Ecosystem Restoration a Social-Ecological Endeavour. Trends Ecolo. Evol. $67636,20-28$.

677 Ghose M., 2001. Management of Topsoil for Geo-environmental Reclamation of Coal 678 Mining Areas. Environ. Geol. 40, 1405-1410.

679 Gobat J-M., Aragno M., Matthey W., 2010. Le sol vivant: bases de pédologie, biologie 680 des sols. Presses polytechniques Universitaires Romandes, Lausanne.

681 Gourmelon V., Maggia L., Powell J.R. , Gigante S., Hortal S., Gueunier C., Letellier K ., 682 Carriconde F., 2016. Environmental and Geographical Factors Structure Soil 
683

684

685

686

687

688

689

690

691

692

693

694

695

696

697

698

699

700

701

702

703

704

705

706

707

Microbial Diversity in New Caledonian Ultramafic Substrates: A Metagenomic Approach. PLoS ONE 11 (12), e0167405. doi:10.1371/journal.pone.0167405.

Griffiths B.S., Hallett P.D., Kuan H.L., Gregory A.S., Watts C.W., Whitmore A.P., 2008. Functional resilience of soil microbial communities depends on both soil structure and microbial community composition. Biol. Fertil. Soils 44, 745-754.

Harris J, Birch P, Short K 1989: Changes in the microbial community and physicochemical characteristics of topsoils stockpiled during opencast mining. Soil Use Manage., 5, 161-168.

Harrison S., Rajakaruna N., 2011. Serpentine: The Evolution and Ecology of a Model System. University of California Press, Berkeley, CA.

Herrera A., Héry M., Stach J.E.M., Jaffré T., Norman P., Navarro E., 2007. Species richness and phylogenetic diversity comparisons of soil microbial communities affected by nickel-mining and revegetation efforts in New Caledonia. Eur. J. Soil Biol. 43, 130-139.

Isnard S., L'huillier L., Rigault F., Jaffré T., 2016. How did the ultramafic soils shape the flora of the New Caledonian hotspot? Plant Soil 403, 53-76.

Jaffré T., L'Huillier L., 2010. La végétation des roches ultramafiques ou terrains miniers, In : L'Huillier L, Jaffré $T$, Wulff $A(E d s)$, Mines et environnement en Nouvelle-Calédonie : les milieux sur substrats ultramafiques et leur restauration. IAC Ed., Noumea, pp. 45-103.

Joergensen R.G., 1996. The fumigation extraction method to estimate microbial biomass : calibration of the kEC value. Soil Biol. Biochem. 28, 25-31.

Karst J., Piculell B., Brigham C., Booth M., Hoeksema J.D., 2013. Fungal communities in soils along a vegetative ecotone. Mycologia 105, 61-70.

Kennedy N., Edwards S., Clipson N., 2005. Soil bacterial and fungal community 
708 structure across a range of unimproved and semi-improved upland grasslands.

709 Microb. Ecol. 50, 463-73.

710 Ko D., Yoo G., Yun S.T., Jun S.C., Chung H. 2017. Bacterial and fungal community

711 composition across the soil depth profiles in a fallow field. J. Ecol. Environ. 41, 34.

712 DOI: $10.1186 / s 41610-017-0053-0$

713 Koch J.M., 2007. Alcoa's mining and restoration process in South Western Australia.

$714 \quad$ Restor. Ecol. 15, 11-16.

715 Kunin V., Engelbrektson A., Ochman H., Hugenholtz P., 2010. Wrinkles in the rare

716 biosphere: pyrosequencing errors can lead to artificial inflation of diversity

717 estimates. Environ. Microbiol. 12, 118-23.

718 Lauber C.L., Strickland M.S., Bradford M.A., Fierer N., 2008. The influence of soil 719 properties on the structure of bacterial and fungal communities across land-use $720 \quad$ types. Soil Biol. Biochem. 40, 2407-2415.

721 L'Huillier L., Jaffré T., 2010. L'exploitation des minerais de nickel en Nouvelle722 Calédonie, In : L'Huillier L, Jaffré T, Wulff A (Eds), Mines et environnement en $723 \quad$ Nouvelle-Calédonie : les milieux sur substrats ultramafiques et leur restauration. $724 \quad$ IAC Ed., Noumea, pp. 21-31.

725 L’Huillier L., Wulff A., Gateblé G., Fogliani B., Zongo C., Jaffré T., 2010. La restauration 726 des sites miniers, In : L'Huillier L, Jaffré T, Wulff A (Eds), Mines et environnement en $727 \quad$ Nouvelle-Calédonie : les milieux sur substrats ultramafiques et leur restauration. 728 IAC Ed., Noumea, pp. 147-230.

729 Li H., Wang X., Liang C., 2015. Aboveground-belowground biodiversity linkages differ 730 in early and late successional temperate forests. Sci. Rep-UK 5, 12234. Doi: $731 \quad 10.1038 /$ srep12234. 
732 Liang H., Wang X., Yan J., Luo L., 2019. Characterizing the Intra-Vineyard Variation of

733 Soil Bacterial and Fungal Communities. Front Microbiol 10, 1239. doi: 734 10.3389/fmicb.2019.01239. eCollection.

735 Marchese C., 2015. Biodiversity hotspots: A shortcut for a more complicated concept. 736 Global Ecol. Conserv. 3, 297-309.

737 Margulies M., Egholm M., Altman W.E., et al., 2005. Genome sequencing in 738 microfabricated high-density picolitre reactors. Nature, 437, 376-380.

739 Mashigo S.K., 2018. Diversity and functional attributes of microorganisms from 740 stockpiled soils of coal mines in Mpumalanga Province, South Africa. Master 741 Dissertation), North-West University, Potchefstroom.

742 McArdle B.H., Anderson M.J., 2001. Fitting multivariate models to community data: a 743 comment on distance-based redundancy analysis. Ecology, 82, 290-297.

744 McDonald T., Jonson J., Dixon K.W., 2016. National standards for the practices of 745 ecological restoration in Australia. Restor. Ecol. 24, S4-S32.

746 McGrath D., 1996. Application of single and sequential extraction procedures to 747 polluted and unpolluted soils. Sci. Tot. Environ. 178, 37-44. doi.org/10.1016/00489697(95)04795-6

McMurdie P.J., Holmes S., 2014. Waste not, want not: why rarefying microbiome data is inadmissible. PLoS comput. Boil. 10, e1003531. doi.org/10.1371/journal.pcbi. 1003531.

Menzies N.W., Donn M.J. and Kopittke P.M., 2007. Evaluation of extractants for estimation of the phytoavailable trace metals in soils. Environ. Pollut. 145, 121130. doi:10.1016/j.envpol.2006.03.021

Morat P, Jaffré T., Muzinger J. Pillon Y., Veillon J-M., Chapolin M., Birnbaum P., Rigault F., Dagostini G., Tinel J., Lowry P., 2012. The taxonomic reference base 
«FLORICAL» and characteristics of the native vascular flora of New-Caledonia. Adansonia 3, 179-221.

Mouillot D., Bellwood D.R., Baraloto C., Chave J., Galzin R., Harmelin-Vivien,Michel Kulbicki H., Lavergne L., Lavorel S., Mouquet N., Paine C.E.T., Renaud J. , Thuiller W., 2013. Rare species support vulnerable function in high-diversity ecosystems. PLoS Boil. 11, e1001569. doi.org/10.1371/journal.pbio.1001569.

Myers N., Mittermeier R.A., Mittermeier C.G., da Fonseca G.A., Kent J., 2000. Biodiversity hotspots for conservation priorities. Nature 403, 853-858.

Nilsson R.H., Tedersoo L., Abarenkov K., Ryberg M., Kristiansson E., Hartmann M., Schoch C.L., Nylander J.A.A, Bergsten J., Porter T.M., Jumpponen A., Vaishampayan P., Ovaskainen O., Hallenberg N., Bengtsson-Palme J., Eriksson K.M., Larsson K.H., Larsson E., Kõljalg U., 2012. Five simple guidelines for establishing basic authenticity and reliability of newly generated fungal ITS sequences. MycoKeys 4,37-63.

Perrier N., Amir H., Colin F., 2006. Occurrence of mycorrhizal symbioses in the metalrich lateritic soils of the Koniambo Massif, New Caledonia. Mycorrhiza 16, 449458.

Proctor J., 2003. Vegetation and soil and plant chemistry on ultramafic rocks in the tropical Far East. Perspect. Plant Ecol. 6, 105-124

Proctor J., Nagy L., 1992. Ultramafic rocks and their vegetation: an overview, In: Baker AJM, Proctor J, Reeves RD (Eds.) The vegetation of ultramafic (serpentine) soils. Intercept Ltd, Andover, pp. 470-495. 
dynamics of bacteria and fungi during litter decomposition. Molecular Ecology

782 25(16), 4059-4074.

783

Quast C., Pruesse E., Yilmaz P. Gerken J., Schweer T., Yarza P., Peplies J., Glöckner F.O., 2013. The SILVA ribosomal RNA gene database project: improved data processing and web-based tools. Nucleic acids res. 41, D590-6. DOI:10.1093/nar/gks1219.

Robertson G. P., Groffman P. M., 2015. Nitrogen transformations, In: Paul, E. A. (ed.), Soil microbiology, ecology and biochemistry. Fourth edition. Academic Press, Burlington, pp. 421-446.

Robinson M.D., McCarthy D.J., Smyth G.K., 2010. edgeR: a Bioconductor package for differential expression analysis of digital gene expression data. Bioinformatics 26, 139-140.

792

Rousk J., Bååth E., Brookes P.C., Lauber C.L., Lozupone C., Caporaso J.G., Knight R., Fierer N., 2010. Soil bacterial and fungal communities across a pH gradient in an arable soil. ISME j. 4, 1340-1351.

Sait M., Davis K.E.R., Janssen P.H., 2006. Effect of pH on Isolation and Distribution of Members of Subdivision 1 of the Phylum Acidobacteria Occurring in Soil. Appl. Environ. Microbiol. 72, 1852-1857.

Sheng Y., Cong W., Yang L., Liu Q., Zhang Y., 2019. Forest Soil Fungal Community Elevational Distribution Pattern and Their Ecological Assembly Processes. Front. $800 \quad$ Microbiol. 10:2226. doi: 10.3389/fmicb.2019.02226.

801 Sheoran V., Sheoran A.S., Poonia P., 2010. Soil Reclamation of Abandoned Mine Land 802 by Revegetation!: A Review. International Journal of Soil Sediment and Water, 3, 1803 21. 
804 Stahl P.D., Perryman B.L., Sharmasarkar S., Munn L.C., 2002. Topsoil Stockpiling Versus

805 Exposure to Traffic: A Case Study on In situ Uranium Wellfields. Restor. Ecol. 10, $806 \quad 129-137$.

807 Strohmayer P., 1999. Soil Stockpiling for Reclamation and Restoration activities after 808 Mining and Construction. Restoration and Reclamation Review 4, 1-6.

809 Tordoff G.M., Baker A.J.M., Willis A. J., 2000. Current approaches to the revegetation 810 and reclamation of metalliferous mine wastes. Chemosphere, 41, 219-228.

811 United Nations Environment Agency Resolution 73/284. 2019. United Nations Decade 812 on Ecosystem Restoration (2021-2030). https://undocs.org/A/RES/73/284.

813 Visser S., Fujikawa J., Griffiths C.L., Parkinson D., 1984. Effect of topsoil storage on 814 microbial activity, primary production and decomposition potential. Plant Soil 82, $815 \quad 41-50$.

816 Waldrop M.P., Zak D.R., Blackwood C.B., Curtis C.D., Tilman D., 2006. Resource 817 availability controls fungal diversity across a plant diversity gradient. Ecol. Lett. 9, $818 \quad 1127-1135$.

819 Waseem M., Ducousso M., Prin Y., Domergue O., Hannibal L., Majorel C., Jourand P., 820 Galiana A., 2017. Ectomycorrhizal fungal diversity associated with endemic 821 Tristaniopsis spp. (Myrtaceae) in ultramafic and volcano-sedimentary soils in New $822 \quad$ Caledonia. Mycorrhiza 27, 407-413.

823 White T.J., Bruns T., Lee S., Taylor J., 1990. Amplification and direct sequencing of 824 fungal ribosomal RNA genes for phylogenetics, In: Innis, M.A., Gelfand, D.H., 825 Sninsky, J.J., and White, T.J. (eds), PCR Protocols: A Guide to Methods and 826 Applications. Academic Press, New York, pp. 315-322.

827 Woese C.R., 1987. Bacterial evolution. Microbiol. Rev. 51, 221-271. 
828 Yergeau E., Bezemer T.M., Hedlund K., Mortimer S.R., Kowalchuk G.A., van der Putten

829 W.H., 2010. Influences of space, soil, nematodes and plants on microbial

830 community composition of chalk grassland soils. Environ. Microbiol. 12, 2096-

8312106.

832 Wang Y., Xu X., Liu T., Wang H., Yang Y., Chen X., Zhu S., 2020. Analysis of bacterial

833 and fungal communities in continuous-cropping ramie (Boehmeria nivea L. Gaud)

834 fields in different areas in China Sci. Rep. 10, 3264. doi: 10.1038/s41598-020-

$835 \quad 58608-0$.

836 Weber C.F., Vilgalys R., Kuske C.R., 2013. Changes in fungal community composition in 837 response to elevated atmospheric $\mathrm{CO} 2$ and nitrogen fertilization varies with soil 838 horizon. Front. Microbiol. 4, 78. doi: 10.3389/fmicb.2013.00078.

839 Wick, A.F., Stahl P.D. , Rana S. , Ingram L.J., 2007. Recovery of reclaimed soil

840 structure and function in relation to plant community composition. In: Thirty 841 years of SMCRA and beyond: Proceedings of the 24th National Meetings of the

842 American Society of Mining and Reclamation, Gillette, WY. 2-7 June 2007. 843 Curran Assoc., Red Hook, NY. pp. 941-957.

844 Yu L., Nicolaisen M., Larsen J., Ravnskov S., 2012. Molecular characterization of root845 associated fungal communities in relation to health status of Pisum sativum using 846 barcoded pyrosequencing. Plant Soil 357, 395-405. 


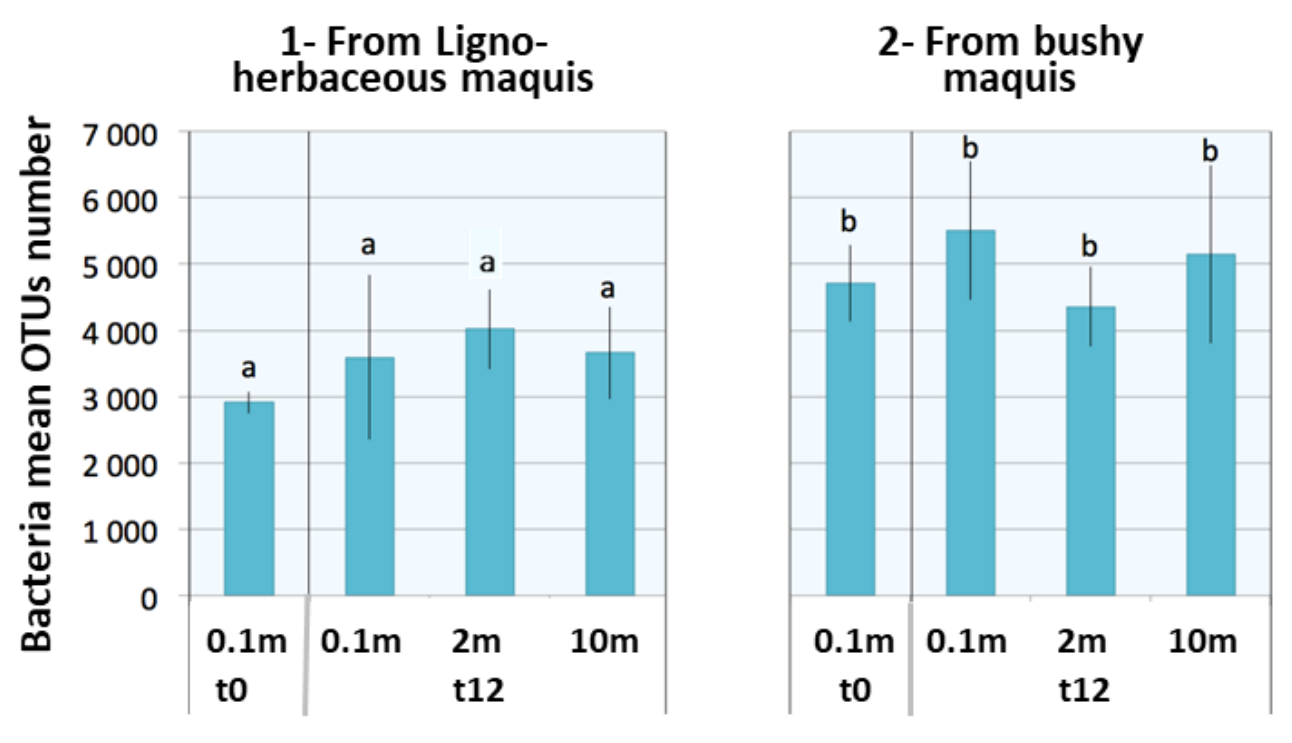

Fig. 1. Bacterial OTU numbers (mean $\pm \mathrm{se}$ ) in 12 months stockpiled topsoils (t12) compared to the non-stored topsoils (t0) at different depth $(0.1 \mathrm{~m}, 2 \mathrm{~m}$ and $10 \mathrm{~m})$. For each graph, bars with the same letter are not significantly different according to a one-way PERMANOVA followed by Pair-wise permutation test $(n=10)$. 
1- From Ligno-herbaceous maquis

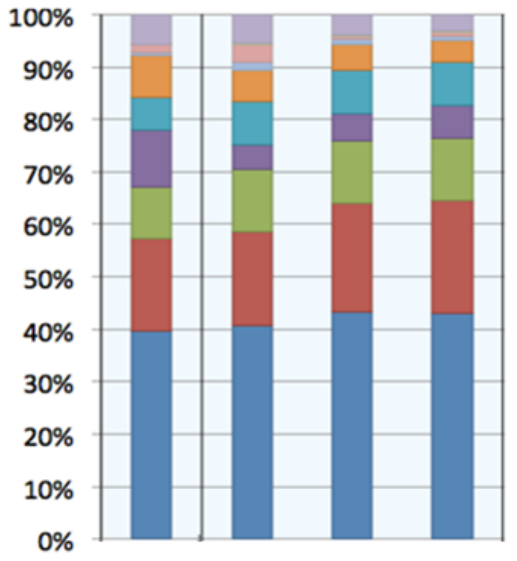

$0 \%$
2- From bushy maquis

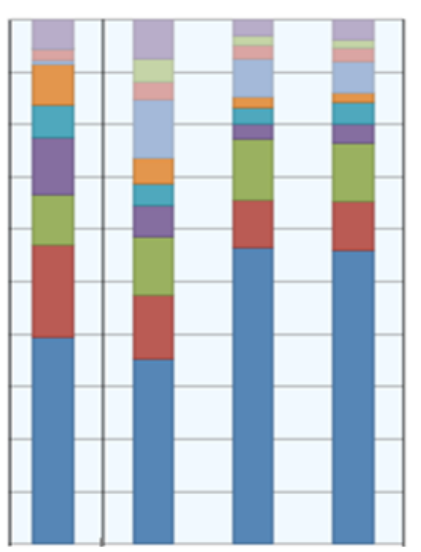

B
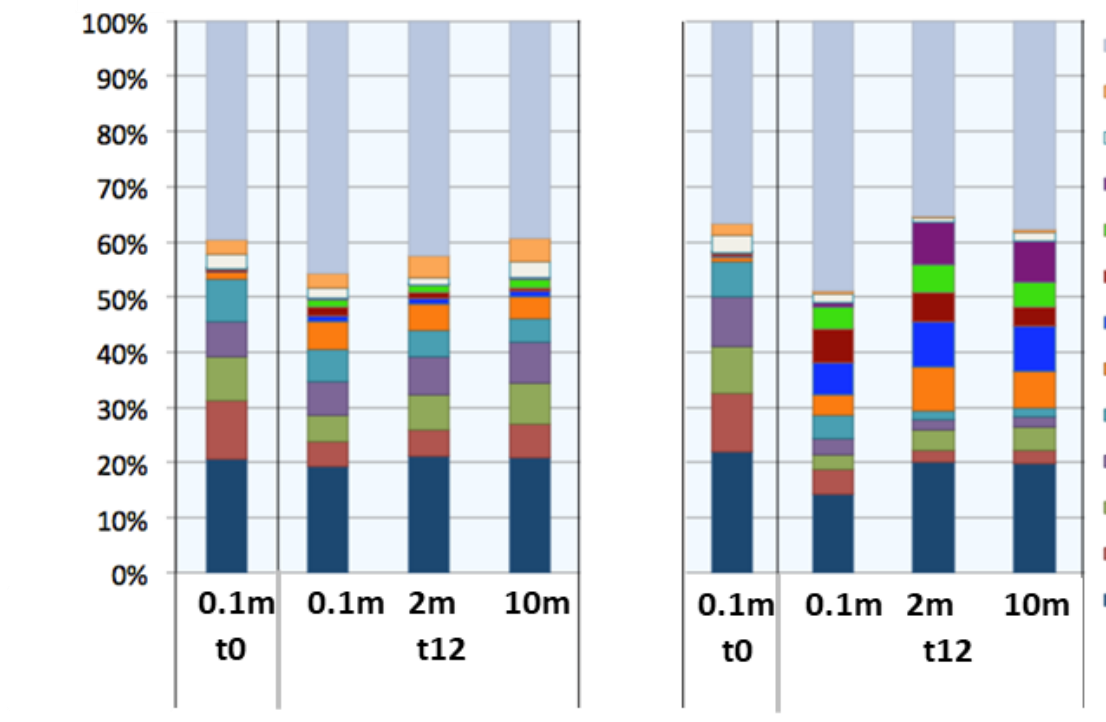

\section{- Others}

p. Candidate_division_TM7

p. Firmicutes

p. Bacteroidetes

p. Verrucomicrobia

p. Chloroflexi

p. Planctomycetes

p. Actinobacteria

口. Acidobacteria

p. Proteobacteria

Others

Ip. Acidobacteria; c. DA052; 0. uncultured bacterium

$\square$ p. Actinobacteria; c. Corynebacteriales; o. Mycobacteriaceae

I. pr. Proteobacteria; c. Betaproteobacteria; o. UCT N117.

p. Actinobacteria; c. Propionibacteriales; o. Nocardioidaceae

-p. Bacteroidetes; c. Sphingobacteriia; 0. Sphingobacteriales

mp. Proteobacteria; c. Alphaproteobacteria; o. Sphingomonadales

=p. Proteobacteria; c. Betaproteobacteria; o. Burkholderiales

E. p. Verrucomicrobia; c. Spartobacteria; o. Chthoniobacterales

-p. Acidobacteria; c. Acidobacteriales; o. Acidobacteriaceae

= p. Proteobacteria; c. Alphaproteobacteria; o. Rhodospirillales

p. Planctomycetes; c. Planctomycetacia; o. Planctomycetales

- p. Proteobacteria; c. Alphaproteobacteria; o. Rhizobiales

Fig. 2. Relative abundance of bacterial phyla (A) and orders (B) in 12 months stockpiled topsoils (t12) compared to the non-stored topsoils (t0). 
Fig. 3

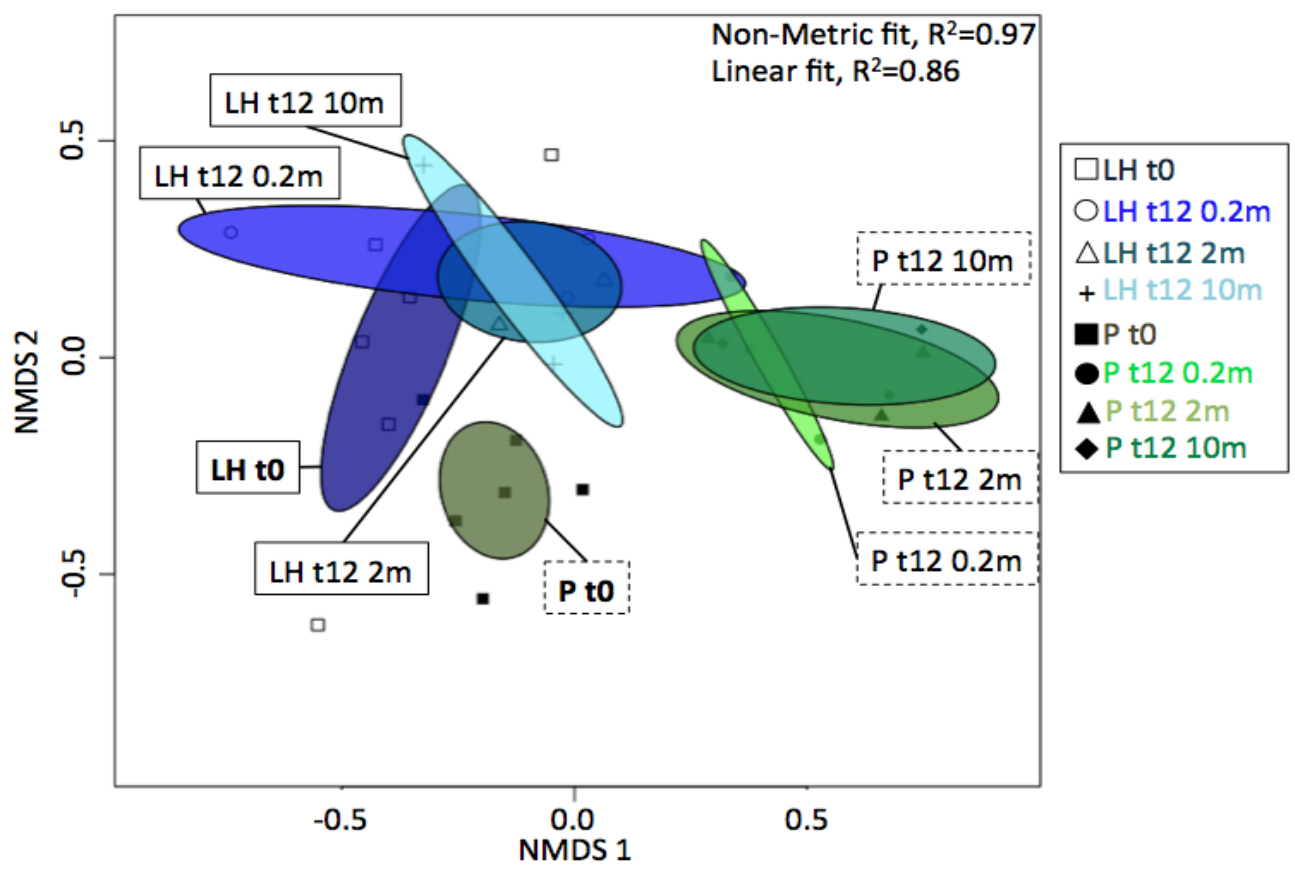

Fig. 3. Non-metric multidimensional scaling analysis (NMDS) of bacterial community structure of 12 months stockpiled topsoils (t12) compared with the non-stored topsoils (t0) at different depth $(0.1 \mathrm{~m}, 2$ $\mathrm{m}$ and $10 \mathrm{~m}$ ). The distance between the ellipses indicates the degree of similarity between the communities. TO bacterial communities differed significantly between the two topsoils and with the corresponding stored topsoils. $\mathrm{LH}=$ ligno-herbaceous maquis topsoil; $\mathrm{P}=$ bushy maquis topsoil. 


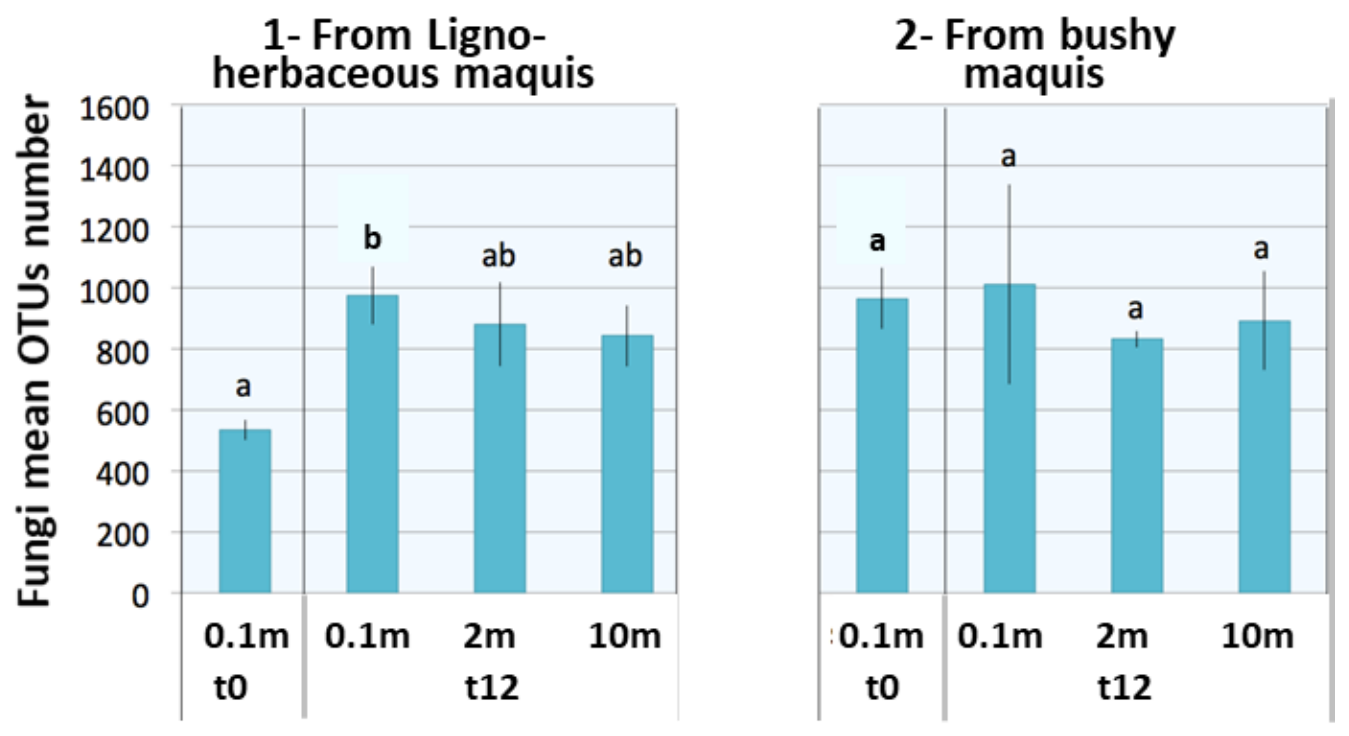

Fig. 4. Fungal OTU numbers (mean $\pm \mathrm{se}$ ) in 12 months stockpiled topsoils (t12) in comparison with the non-stored corresponding topsoil (t0) at different depth $(0.1 \mathrm{~m}, 2 \mathrm{~m}$ and $10 \mathrm{~m})$. For each graph, bars with the same letter are not significantly different according to a one-way PERMANOVA followed by Pair-wise permutation test $(n=10)$. The topsoil 2 was found significantly richer than topsoil 1 at t0. 
1- From Ligno-herbaceous maquis
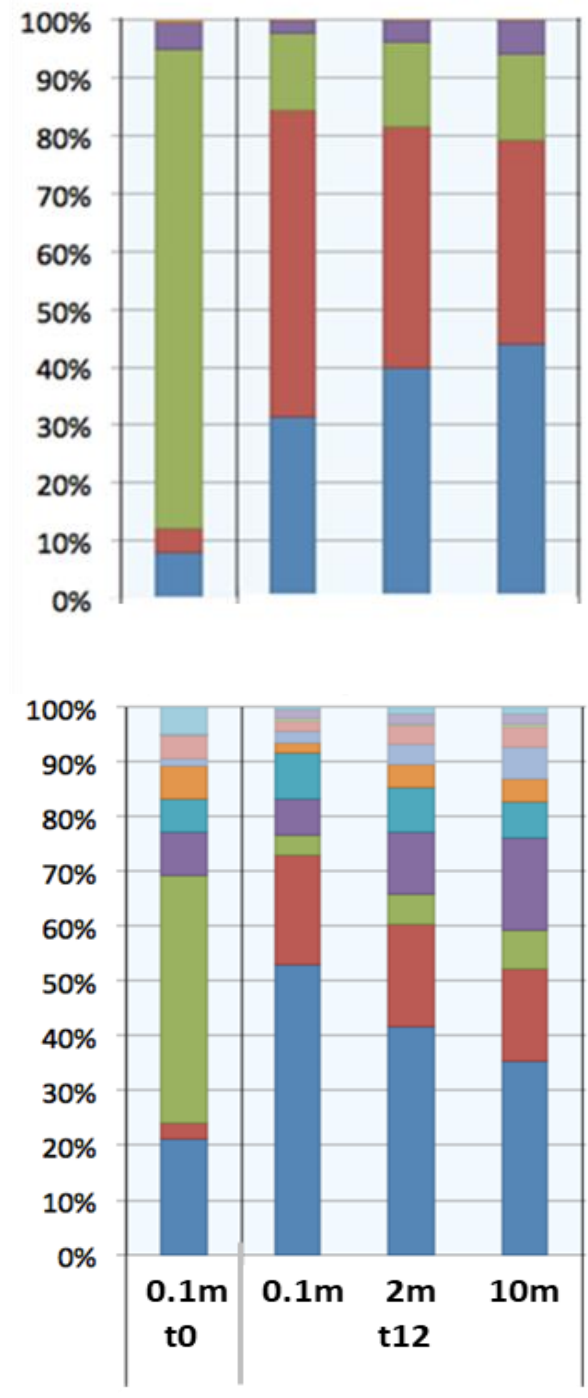

2- From bushy maquis
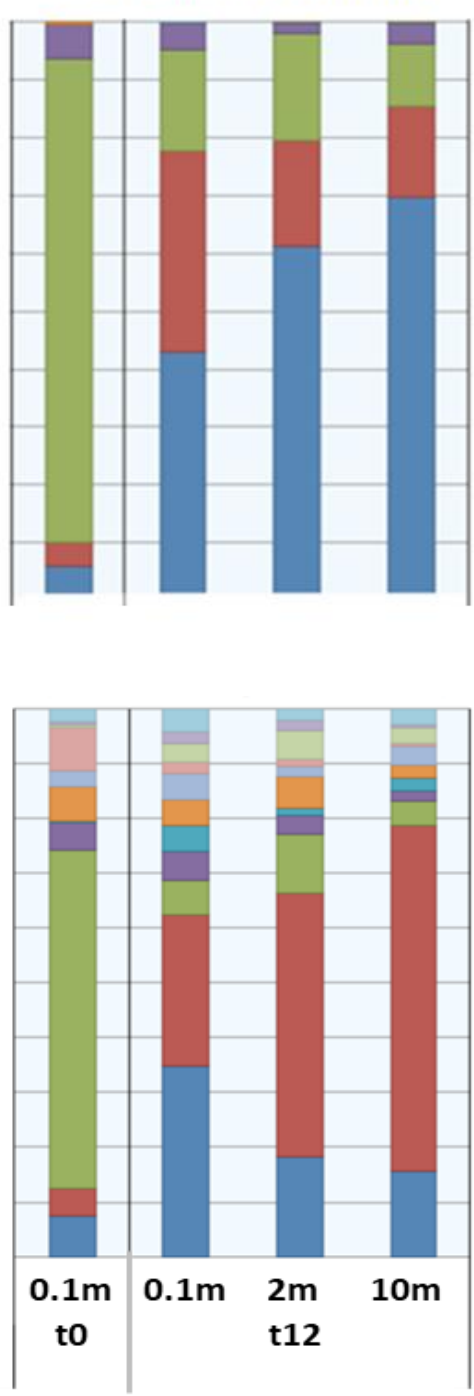

A

E. p. Blastocladiomycota

E. p. Glomeromycota

E. p. Chytridiomycota

ap. Zygomycota

" p. Basidiomycota

=p. unidentified

Ep. Ascomycota
B

\section{= Others}

E. p. Ascomycota; c. unidentified

-p. Basidiomycota; c. Tremellomycetes =p. Ascomycota; c. Leotiomycetes

=p. Zygomycota; c. Incertae sedis

= p. Ascomycota; c. Dothideomycetes

=p. Basidiomycota; c. Wallemiomycetes

Шp. Ascomycota; c. Eurotiomycetes

E. p. Basidiomycota; c. Agaricomycetes

- p. Ascomycota; c. Sordariomycetes

E. unidentified; c. unidentified

Fig. 5. Relative abundance of fungal phyla (A) and classes (B) in 12 months stockpiled topsoils (t12) in comparison with the non-stored corresponding topsoil (t0). 
Fig. 6

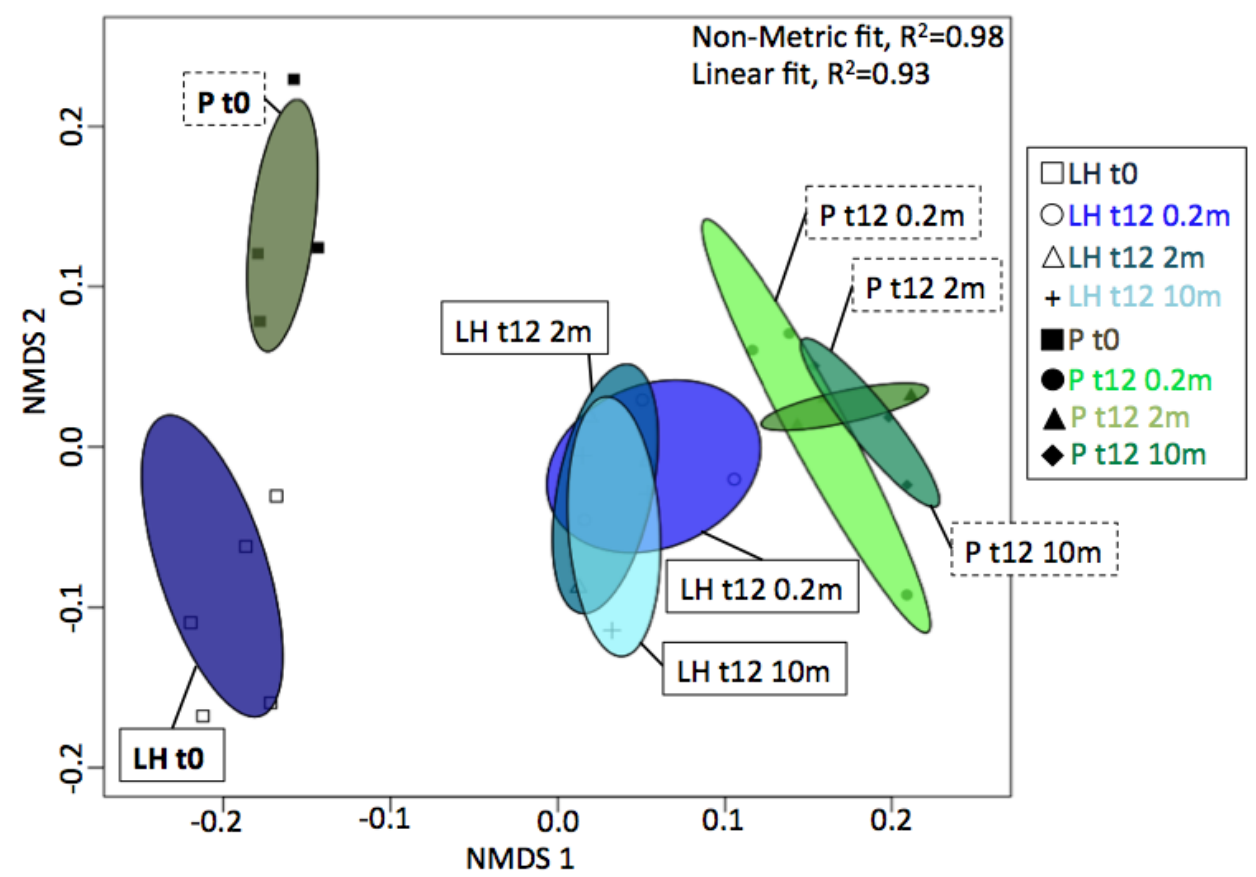

Fig. 6. Non-metric multidimensional scaling analysis (NMDS) of fungal community structure of 12 months stockpiled topsoils (t12) in comparison with the non-stored corresponding topsoil (t0) at different depth $(0.1 \mathrm{~m}, 2 \mathrm{~m}$ and $10 \mathrm{~m})$. The distance between the ellipses indicates the degree of similarity between the communities. T0 fungal communities differed significantly between the two topsoils and with the corresponding stored topsoils. $\mathrm{LH}=$ ligno-herbaceous maquis topsoil; $\mathrm{P}=$ bushy maquis topsoil. 

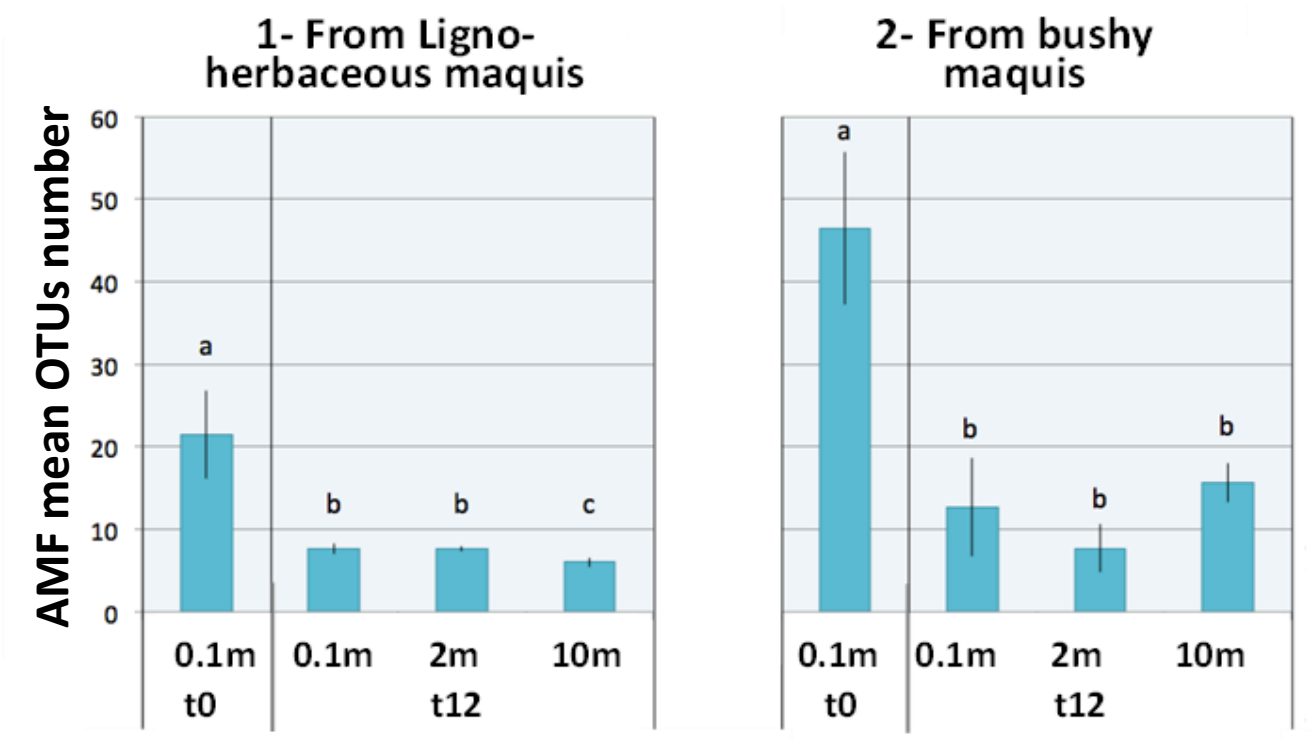

Fig. 7. AMF OTU numbers (mean $\pm \mathrm{se}$ ) in 12 months stockpiled topsoils (t12) compared with the nonstored topsoils (t0) at different depth $(0.1 \mathrm{~m}, 2 \mathrm{~m}$ and $10 \mathrm{~m})$. For each graph, bars with the same letter are not significantly different according to a one-way PERMANOVA followed by Pair-wise permutation test $(n=10)$. 
Fig. 8

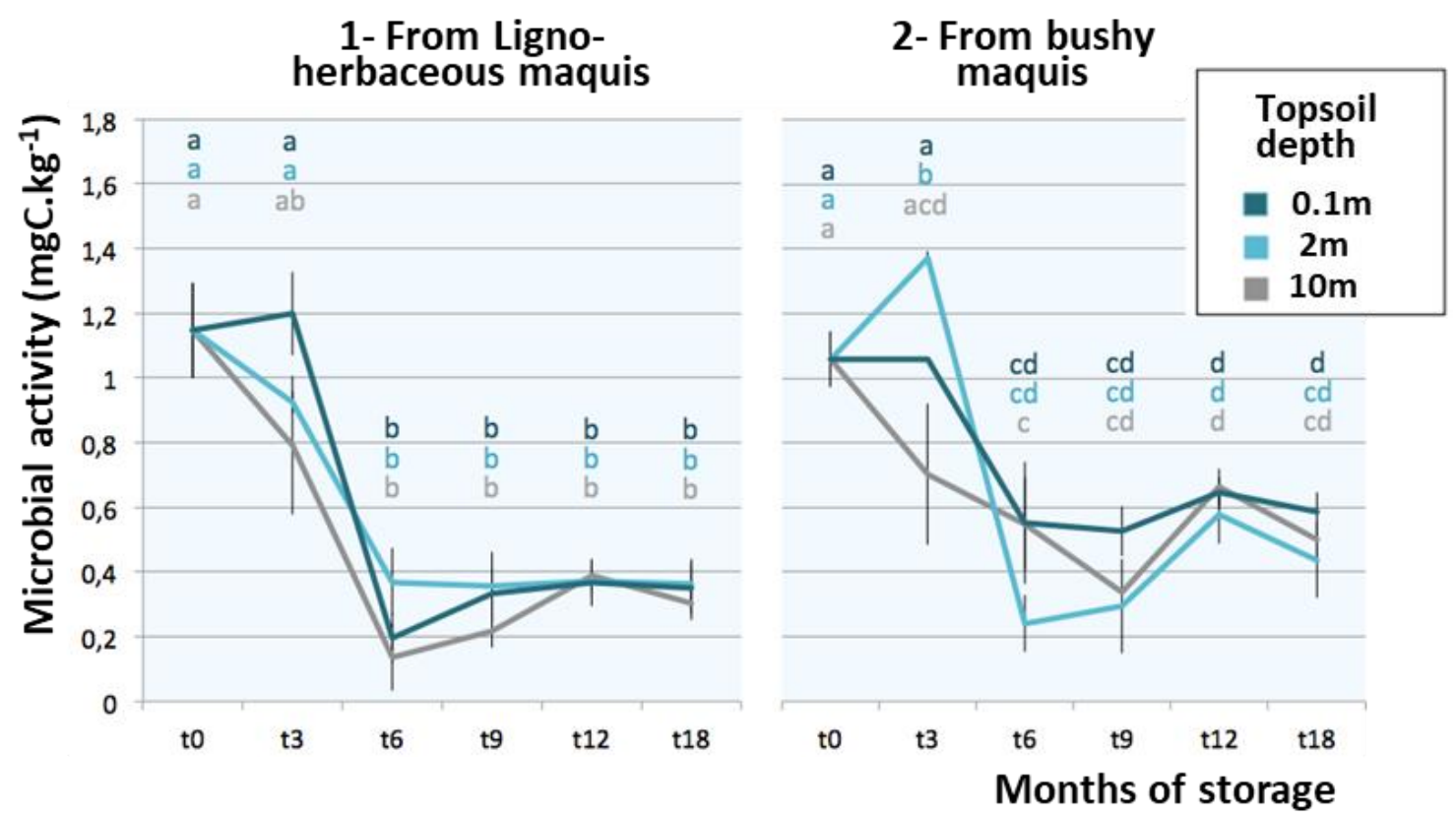

Fig. 8. Evolution of the microbial activity (carbon mineralisation) of stockpiled topsoils in relation to time storage and depth. For each graph, means with the same letter are not significantly different according to a two-way PERMANOVA followed by Pair-wise permutation test ( $\mathrm{n}=6$ mixed 2 by 2 ). 
Fig. 9

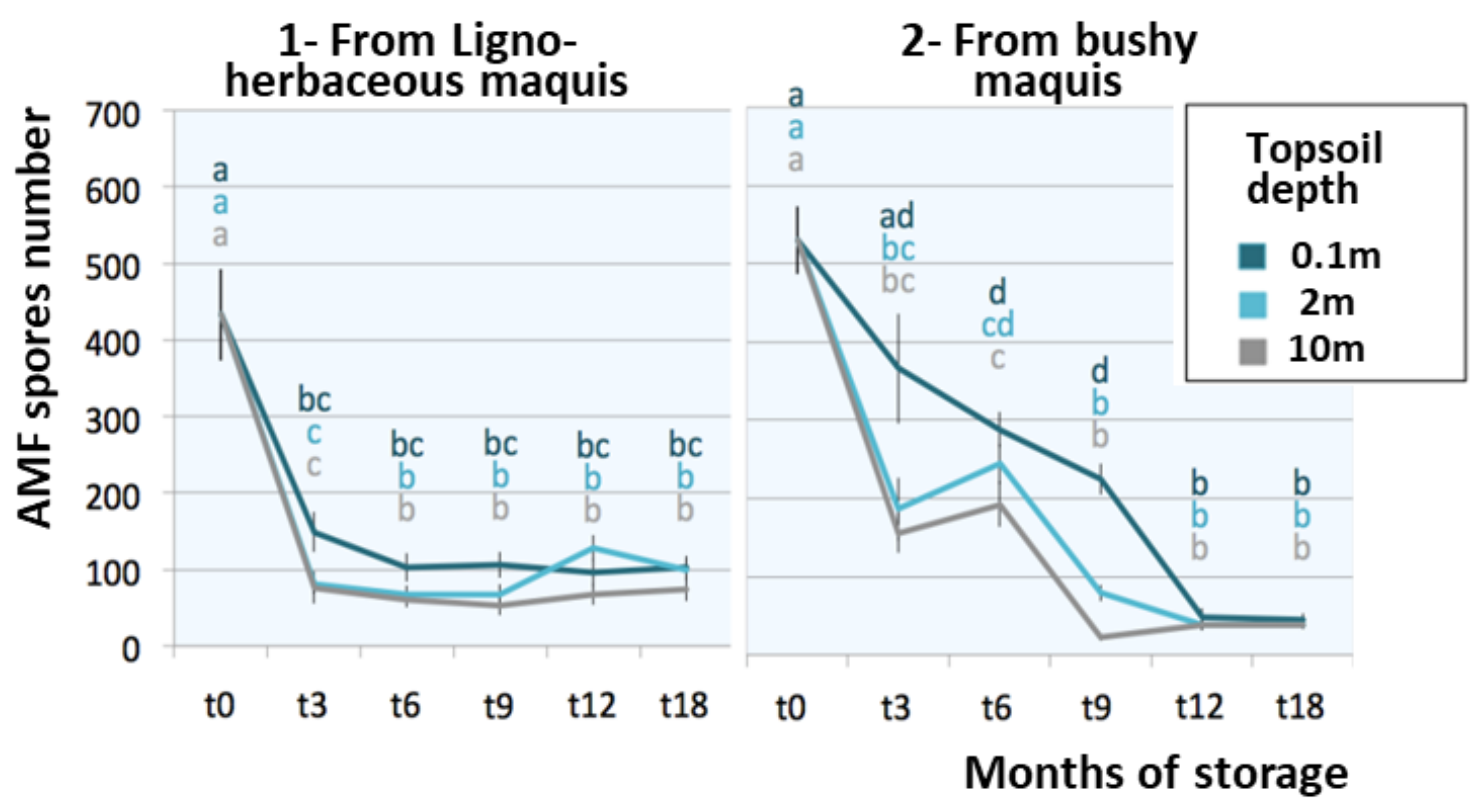

Fig. 9. Evolution of viable AMF spore numbers in stockpiled topsoils in relation to time storage and depth. For each graph, means with the same letter are not significantly different according to a two-way PERMANOVA followed by Pair-wise permutation test ( $n=6$ mixed 2 by 2 ). 
Fig. 10

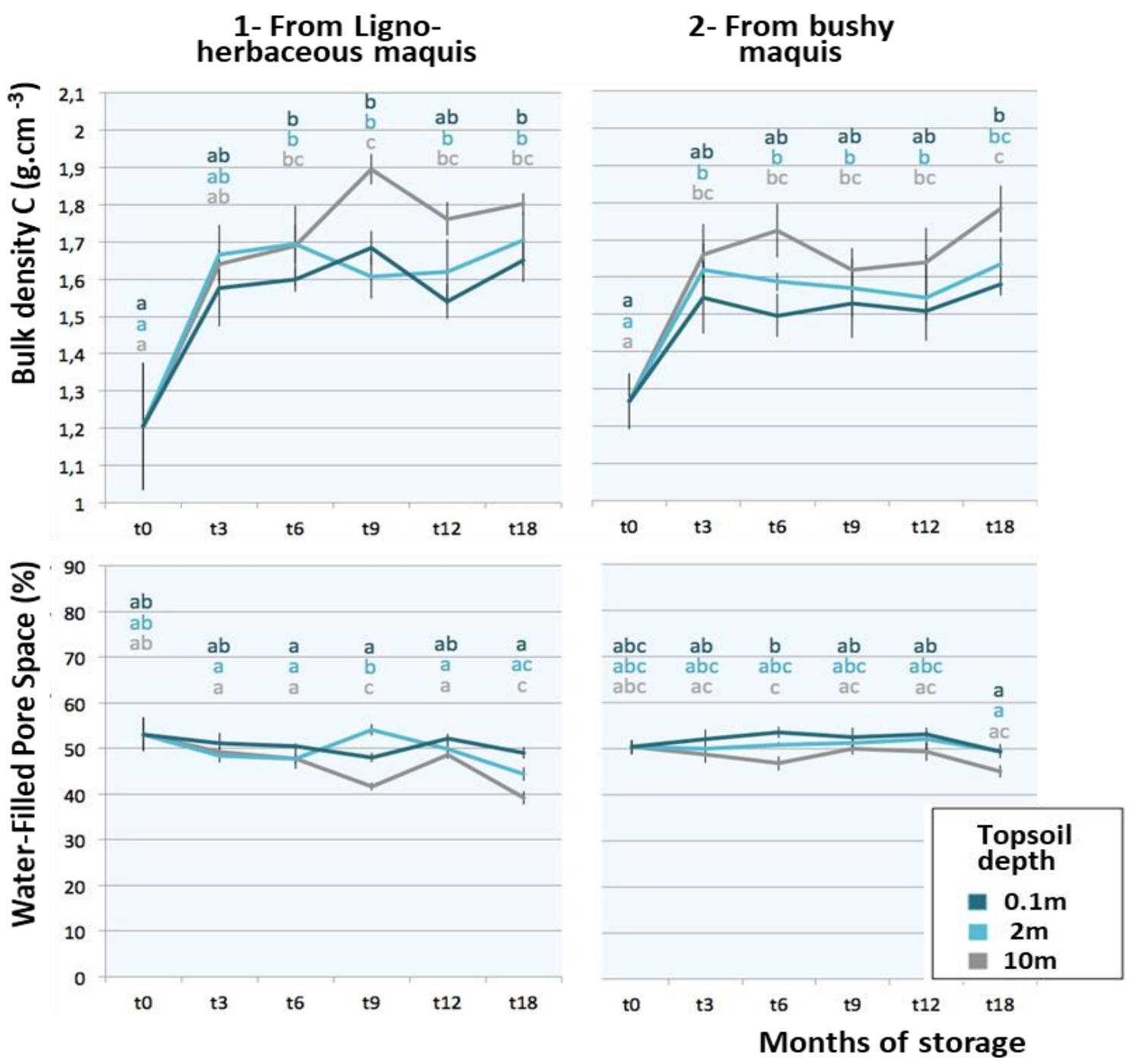

Fig. 10. Evolution of bulk density and water-filled pore space of stockpiled topsoils in relation to time storage and depth. For each graph, means with the same letter are not significantly different according to a two-way PERMANOVA followed by Pair-wise permutation test $(n=4)$. 
Fig. 11

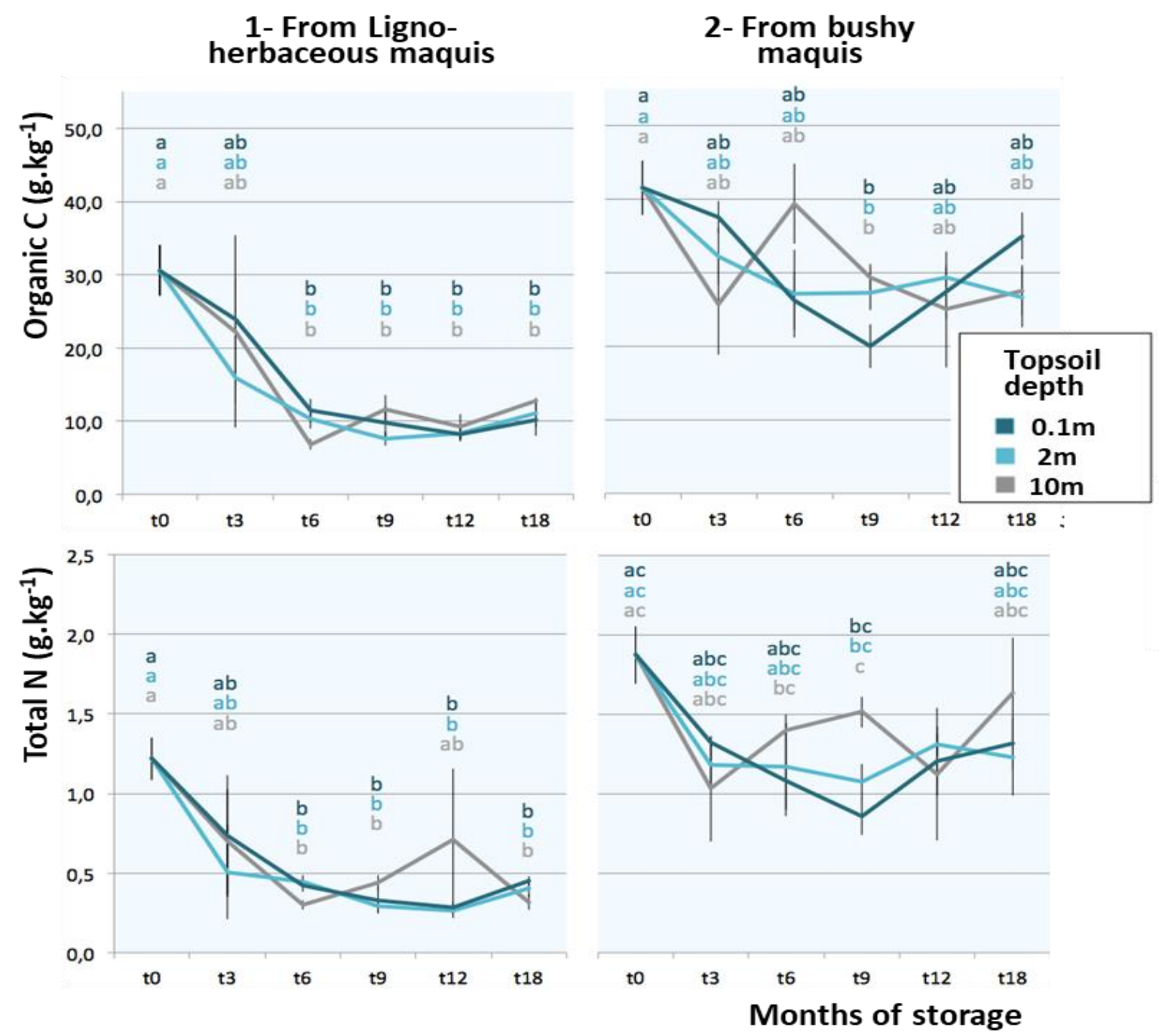

Fig. 11. Evolution of organic carbon and total nitrogen of stockpiled topsoils in relation to time storage and depth. For each graph, means with the same letter are not significantly different according to a two-way PERMANOVA followed by Pair-wise permutation test $(n=4)$. 
Click here to access/download Supplementary Material Supdata Figs and Tabs.docx 